\title{
MOGUĆI PRAVCI IZMJENA I DOPUNA HRVATSKOGA PRAVA DRUŠTAVA
}

Dr. sc. Tomislav Jakšić, docent

Dr. sc. Siniša Petrović, redoviti profesor

Pravni fakultet Sveučilišta u Zagrebu
UDK: 347.72(497.5)

Ur.: 12. srpnja 2016.

Pr.: 21. listopada 2016.

Izvorni znanstveni rad

\section{Sažetak}

Rad daje smjernice nekih budućih izmjena $i$ dopuna domaćeg prava društva kojima se teži stvaranju konkurentnijeg i jasnijeg pravnog okvira koji će biti jednako privlačan domaćim i stranim poduzetnicima. Konkurentan i jasan pravni okvir može pridonijeti jačanju domaćega gospodarstva i pravne sigurnosti te stvaranju povoljne poduzetničke klime. Rad je podijeljen na dva osnovna dijela. U prvom se dijelu daju prijedlozi za izmjene i dopune zakonskoga rješenja na području osnivanja trgovačkih društava. Tako se, primjerice, analizira mogućnost uspostave one stop shop usluge i online osnivanja trgovačkog društva, uvođenje društva kapitala bez zahtjeva minimalnog iznosa temeljnoga kapitala, kao i druge mogućnosti usmjerene na pojednostavljenje osnivanja trgovačkih društva u Hrvatskoj (npr. ukidanje izjave osnivača da nisu porezni dužnici). $U$ drugom se dijelu rada analiziraju, a potom i daju određeni prijedlozi usmjereni na poboljšanje postojećih zakonskih rješenja i uklanjanje nejasnoća koje narušavaju pravnu sigurnosti, a mogu dovesti i do neujednačenih rezultata u poslovnoj i sudskoj praksi. Tako se, primjerice, daju prijedlozi za uređenje mogućnosti davanja razrješnice članovima organa društva s ograničenom odgovornošću, odlučivanje članova upotrebom drugih sredstava komunikacije izvan skupštine društva s ograničenom odgovornošću, odobrenje nagrade članovima prvog nadzornog odbora dioničkog društva, sudjelovanje članova uprave na sjednicama nadzornog odbora te stavljanje protuprijedloga dioničara prije početka $i$ tijekom glavne skupštine društva.

Ključne riječi: pravo društava, osnivanje trgovačkog društva, dioničko društvo, društvo s ograničenom odgovornošću, organi društva, dioničari, članovi društva.

\section{UVOD}

Zakonom o trgovačkim društvima iz 1993. godine (dalje: ZTD) uspostavljen je prvi suvremeni sustav prava društava u Republici Hrvatskoj. Takav sustav izgrađen je po uzoru na njemačko pravo društava koje je bilo uzor i drugim državama istočne 
Europe. ${ }^{1}$ Od njegova donošenja 1993. godine i stupanja na snagu početkom 1995. ZTD je nekoliko puta mijenjan, uglavnom radi usklađivanja s europskim pravom, no konceptualno nije bilo promjena. Značajniji je zahvat bilo uvođenje jednostavnog društva s ograničenom odgovornošću koje nije novi pravni oblik, nego samo društvo s ograničenom odgovornošću na koje se primjenjuju neka posebna pravila zbog njegove veličine i opsega poslovanja. ${ }^{2} \mathrm{U}$ različitim izvještajima o uvjetima poslovanja ${ }^{3}$ Hrvatska redovito ne prolazi onako dobro kao što bismo željeli. Na uvjete poslovanja utječu i drugi čimbenici (npr. porezni aspekti, učinkovitost pravosuđa, opće stanje gospodarstva kao i cijena radne snage), ali neki aspekti baš prava društva itekako determiniraju odluku potencijalnih ulagateljima o tome hoće li investirati u Hrvatsku ili neku drugu državu. To su, primjerice, pitanja vezana uz osnivanje trgovačkih društava, brzinu, jednostavnost i pravnu sigurnost, ali i uz uvjete poslovanja nakon osnivanja, a tiču se općih pravila o ustroju trgovačkog društva, načina donošenja odluka, zaštite članova društva i sl.

Rad ne teži tomu da se njime dade sveobuhvatna i potpuno iscrpna analiza svih mogućih izmjena pravila prava društava, ali se njime daje prikaz nekih izabranih pitanja, kako bi se time otvorila rasprava o mogućim promjenama nekih pravnih instituta, ali moguće i konceptualnih promjena glede osnivanja i djelovanja trgovačkih društava. Ideja nije samo da se time zadovolje zahtjevi iz nekih spomenutih studija o uvjetima poslovanja, nego da se stvore istinski privlačna pravila za poduzetnike koja će služiti prije svega hrvatskim građanima.

\section{OSNIVANJE TRGOVAČKOG DRUŠTVA}

U suvremenom pravnom prometu prevladavaju društva kapitala, posebice društva koja odgovaraju društvu s ograničenom odgovornošću. ${ }^{4}$ To je ponajprije posljedica određenih prednosti društava kapitala nad društvima osoba. Tako su sva društva kapitala pravne osobe, imaju temeljni kapital, a redovito ih može osnovati samo jedna osoba pri čemu nije važan osoban doprinos člana društva jer poslove društva vode organi u kojem mogu djelovati stručne osobe koje ne moraju biti članovi društva. ${ }^{5}$ Najznačajnija prednost takvih društava, međutim, leži u neodgovornosti

1 Tako vidi Barbić, J., Pravo društava, Knjiga prava, Opći dio, 3. izd., str. 101-102.

2 Više o jednostavnom društvu s ograničenom odgovornošću vidi kasnije poglavlje 2.2. Trenutno stanje hrvatskoga prava društava i de lege ferenda prijedlozi.

3 Tako, primjerice, vidi službene statističke stranice Svjetske banke (http://data.worldbank.org/) i službene statističke stranice Svjetskog ekonomskog foruma (http://reports.weforum.org/).

4 Tako primjerice 2013. godine u Hrvatskoj na društva kapitala otpadalo je od 145 tisuća pravnih subjekata oko 90 tisuća pravnih subjekata. U Ujedinjenom Kraljevstvu od oko 2 milijuna pravnih subjekata, na društva kapitala otpada oko 1,5 milijuna subjekata. Takav omjer pravnih subjekata u korist društava kapitala nije prisutan u svim državama članicama što valja pripisati tradicionalno strožim pravilima za osnivanje takvih društava, a i većem broju raznih oblika društava koji poduzetnicima stoje na raspolaganju. Tako je primjerice u Njemačkoj, gdje tek oko jedna petina pravnih subjekata čine društva kapitala, ali i u Francuskoj gdje je omjer nešto povoljniji odnosno gdje oko polovicu pravnih subjekata čine društva kapitala. Izvor Eurostat (http://ec.europa.eu/eurostat/web/main/home).

5 U tom smjeru vidi Barbić, J., Pravo društava, Knjiga prva, Opći dio, 3. izd., str. 157. 
članova za obveze društva. Članovi tako snose samo poslovni rizik odnosno rizik gubitka članskih prava u društvu i u pravilu ne odgovaraju za njegove obveze. ${ }^{6}$ To znači kako imovinu članova ne mogu zahvatiti vjerovnici koji svoja potraživanja ne mogu namiriti od društva.

Osnivanje, kao jedan od načina nastanka društva, obuhvaća postupak nastanka za koji se može reći kako društvo pravna osoba nastaje originarno odnosno „iz početka“.7 Takav postupak obuhvaća, pored sklapanja pravnog posla na kojem se temelji društvo (statut, društveni ugovor), više radnji koje podrazumijevaju provjeru od nadležnog tijela (npr. suda) o ispunjenju svih uvjeta za nastanak pravne osobe (npr. uplata uloga, davanje potrebnih izjava i sklapanja ugovora određenog sadržaja). Osnivanje je konstitutivne naravi te se, barem u Hrvatskoj, temelji na normativnom sustavu. Ispunjenjem zakonom određenih pretpostavki, nadležno tijelo dopušta upis pravnog subjekta u odgovarajući registar.

Osnivanje trgovačkog društava redovito je područje od posebnog interesa poduzetnicima koji žele osnovati društvo kako bi započeli obavljati svoju gospodarsku djelatnost. ${ }^{8}$ Troškovi, trajanje i jednostavnost samog postupka osnivanja smatraju se jednim od važnijih čimbenika pri donošenju odluke poduzetnika o osnivanju određenog tipa društva. Stoga ne čudi ni to što je zamjetan broj nacionalnih zakonodavaca unutar zadnjih petnaestak godina izmjenama svojega nacionalnog prava društava zahvatio i postupak osnivanja. ${ }^{9} \mathrm{U}$ svjetlu težnje za jačanjem konkurentnosti nacionalnog prava, takve su izmjene i dopune bile redovito usmjerene na pojednostavljenje i olakšavanje postupka osnivanja društava odnosno na tzv. deregulaciju postojećega zakonskog okvira.

Nakon uvodnih izlaganja, u nastavku će se ponajprije obraditi zakonska rješenja pojedinih država nakon čega će se takva rješenja poredbenopravno analizirati $\mathrm{s}$ rješenjima ZTD-a. Temeljem iznesenog na kraju se daju razumni i prihvatljivi de lege ferenda prijedlozi usmjereni na pojednostavljenje i olakšanje postupka osnivanja društva s ograničenom odgovornošću.

6 Iznimno članovi mogu odgovarati za obveze društva u slučaju proboja pravne osobnosti (čl. 10. st. 3. i st. 4. ZTD).

7 Tako vidi Barbić, J., Pravo društava, Knjiga druga, Društva kapitala, Svezak I., Dioničko društvo, 6. izd., str. 182-183. Osim na taj način, društvo pravna osoba u pravilu može primjerice nastati preoblikovanjem, spajanjem i podjelom. Općenito o tome vidi Barbić, J., Pravo društava, Knjiga druga, Društva kapitala, Svezak I., Dioničko društvo, 6. izd., str. 179-182.

$8 \mathrm{U}$ tom smjeru vidi dokument UNCITRALA - Best practices in business registration, Note by the Secretariat, A/CN.9/WG.I/WP.85 od 5. rujna 2014. godine, para. 2. Dostupno na službenim internet stranicama UNCITRALA (www.uncitral.org).

9 Tako, primjerice, Nizozemska 2012. godine, Ujedinjeno Kraljevstvo 2006. godine, Francuska više puta u razdoblju od 2000. do 2016. godine i Njemačka 2008. godine. Više o takvim izmjenama za navedene države vidi u narednim poglavljima u tekstu. 


\subsection{Iskustva drugih država}

\subsubsection{Novi Zeland}

Novi Zeland nalazi se u samom vrhu corporate friendly environment država. ${ }^{10}$ Tomu je pridonio Zakon o društvima iz 1993. godine (dalje: NZCA) kojim su učinjene značajne izmjene i dopune dotadašnjega pravnog okvira za osnivanje društava. ${ }^{11}$ Tako je, primjerice, napušteno pravilo o minimalnom iznosu temeljnoga kapitala kojeg članovi društva moraju unijeti u društvo, a udaren je i temelj za ubrzavanje samog postupka osnivanja. Vezano uz pravne oblike, u Novom Zelandu moguće je osnovati više tipova društava (npr. Limited Liability Company, Company Limited by a Guarantee, Cooperative Company, Partnership and Propietorship). Od navedenih, hrvatskom društvu s ograničenom odgovornošću najviše odgovara Limited Liability Company (dalje: LLC), a o kojem će stoga nadalje biti riječi sa stajališta osnivanja toga društva.

Kako bi LLC bio osnovan mora imati ime, barem jednog člana društva i jedan udio, jednog direktora, sjedište i poslovnu adresu. ${ }^{12}$ Postupak osnivanja pritom nije složen jer se svi potrebni dokumenti nalaze u obliku prethodno pripremljenih obrazaca (formulara) koje je potrebno samo odgovarajuće popuniti. ${ }^{13}$ Tako, primjerice, prijava za osnivanje društva, pored detalja o samom društvu (npr. naziv tvrtke, sjedište, poslovna adresa), mora sadržavati i osnovne podatke o direktorima društva, osnivačima i njihovim udjelima u društvu. Popunjavanje takvih obrazaca nije zahtjevno te se može učiniti brzo ako su onome tko ih popunjava (npr. jedinom članu društva ili njegovom punomoćniku) dostupni svi potrebni podatci (npr. adrese direktora i članova društva, mjesta i datumi njihova rođenja). Nakon popunjavanja, takve je obrasce potrebno dostaviti nadležnom registracijskom tijelu (engl. Registar of Companies), a prijavu je moguće učiniti i online pri čemu je moguće učiniti i rezervaciju naziva tvrtke društva. Nakon prijave, nadležnom tijelu potrebno je dostaviti dodatne propisane obrasce (potpisane izjave članova i direktora društva) u daljnjem roku od 20 radnih dana. $\mathrm{Ne}$ primi li nadležno tijelo sve potrebne dokumente u tom roku, postupak registracije valja pokrenuti iznova. Trošak osnivanja iznosi oko 160 NZD-a. Po primitku svih uredno popunjenih dokumenata, nadležno tijelo vrši registraciju i izdaje potvrdu o osnivanju društva (engl. certificate of incorporation). Registracijom društvo stječe pravnu osobnost odnosno pravnu i poslovnu sposobnost. ${ }^{14}$

Pritom valja naglasiti kako temeljni akt društva (engl. company constitution)

10 Prema statističkim indikatorima Svjetske banke Novi Zeland nalazi se na drugom mjestu u svijetu po lakoći obavljanja gospodarske djelatnosti (ease of doing business), društvo je moguće osnovati u jedan dan (time required to start a business) pri čemu je potrebno poduzeti samo jednu radnju (start-up procedures to register a business). Više o tomu na službenim statističkim stranicama Svjetske banke (http://data.worldbank.org/).

11 Engl. Companies Act 1993, 28. 9. 1993., Public Act 1993 No. 105 (http://www.legislation.govt. $\mathrm{nz} /$ ).

12 Tako vidi čl. 10. NZCA.

13 Tako vidi First Schedule to the Companies Act 1993 Regulations 1994, SR 1994/118 (http:// www.legislation.govt.nz/).

14 Tako vidi čl. 16. st. 1. NZCA. 
uopće nije potrebno sastaviti i dostaviti nadležnom tijelu u postupku osnivanja. To je stoga što NZCA, sam po sebi, određuje pravila koja uređuju funkcioniranje i djelovanje društva. Takav okvir može se u zakonom dopuštenoj mjeri izmijeniti donošenjem temeljnog akta društva. To znači kako je pri osnivanju društva, a i nakon njegova osnutka, moguće usvojiti takav temeljni akt kojim se zakonom dispozitivno uređena pitanja uređuju drukčije. ${ }^{15}$ Tako će manja društva redovito moći takvim posebnim aktom ograničiti prijenos udjela u društvu na treće osobe izvan društva, a veća će društva, primjerice, moći urediti posebne rezerve za određene namjene te tako iskoristiti prednosti uređenja strukture kapitala društva ili odrediti pravo društva na stjecanje vlastitih udjela $\mathrm{u}$ društvu. ${ }^{16} \mathrm{~S}$ druge strana, takvim temeljnim aktom nije, primjerice, moguće promijeniti pravilo prema kojem se bez pristanaka posebne skupštine članova koji drže povlaštene udjele ne mogu smanjivati njihova članska prava u društvu. ${ }^{17}$

Vjerojatno najvažnije svojstvo NZCA u postupku osnivanja, a koje dijele i neke druge države (npr. Japan i Australija), nalazimo u pravilu o nepostojanju minimalnog iznosa temeljnoga kapitala koje valja unijeti u društvo u postupku osnivanja odnosno originarnog izdavanja udjela društva. ${ }^{18}$ Drugim riječima, osnivači društva nisu dužni pri stjecanju udjela u društvu unijeti bilo kakvu vrijednost na ime temeljnoga kapitala društva. Pri osnivanju društva dovoljan je samo njihov pristanak o preuzimanju udjela u društvu. To ne znači kako se osnivači ne mogu obvezati uplatiti određene iznose društvu za udjele koje stječu. To je moguće odrediti temeljnim aktom društva ili ugovorom s društvom koji može biti sklopljen prije ili nakon osnutka društva. ${ }^{19}$ Pritom valja naglasiti kako protučinidba za stjecanje udjela, osim uplate u novcu, u

15 Tako prema članku čl. 27. NZCA kod društva koje ima temeljni akt, društvo, upravni odbor, svaki direktor i svaki član društva imaju prava, ovlasti i obveze kako određuje zakon, osim u mjeri u kojoj je to izmijenjeno takvim temeljenim aktom, ali u skladu sa zakonom. Više o tome vidi Williams, G., New Zealand, Corporations and Partnerships, Supplement 5, May 2011, paras. 116, 161-163, 167.

16 U tom smjeru vidi Williams, G., New Zealand, Corporations and Partnerships, Supplement 5, May 2011, para. 161. Ovdje valja naglasiti kako je temeljni kapital društava u državama anglosaksonskoga pravnog kruga podijeljen na udjele (engl. share). To znači kako takvi pravni sustavi, za razliku od država germanskoga pravnog kruga, ne razlikuju dionice i poslovne udjele. Tako, primjerice, engleski public company limited by shares (PLC) i private company limited by shares (LTD) imaju udjele kao sredstvo izražavanja članstva u društvu sudjelovanjem u njegovu temeljnom kapitalu (engl. share capital). Ovisno o tomu radi li se o prvom ili drugom društvu, takve je udjele moguće, odnosno nije moguće nuditi javnosti. Tako, primjerice, vidi čl. 4. i čl. 755. Companies Act.

17 Tako vidi odredbu čl. 117. st. 1. NZCA.

18 Tako za Japan vidi, primjerice, Kawamoto, I., Kawaguchi, Y., Kihira, T., Japan, Corporations and Partnerships, Supplement 64, July 2012, paras. 254-256. Tako za Australiju vidi, primjerice, Fletcher, K., Australia, Corporations and Partnerships, Supplement 43, July 2008, para. 58. Više o posljednjoj reformi japanskoga prava društava. Vidi Goto, G., The Outline for the Companies Act Reform in Japan and Its Implications, Journal of Japanese Law, vol. 35 (2013), str. 14-36.

19 Tako vidi odredbu čl. 46A. NZCA. Ako se radi o ugovoru između članova društva i osobe koja sklapa takav posao u ime odnosno za račun takvog društva, takav se ugovor može ispuniti tek nakon osnutka društva jer takav ugovor društvo po osnutku valja ratificirati. Više o ratifikaciji, vidi sljedeći paragraf ovoga rada. 
stvarima i pravima, mogu biti i ugovori za buduće usluge. ${ }^{20}$

Unatoč postupcima koji bitno olakšavaju osnivanje društava u Novom Zelandu, vezano uz obavljanje poslovne djelatnosti u stadiju prije osnutka društva (tzv. stadij preddruštva), NZCA nameće određena ograničenja koja mogu negativno utjecati na donošenje odluke na osnivanje društva. Takva se ograničenja ogledaju u učinku pravnih radnji koje su posljedica takve poslovne djelatnosti. Poslove koji će biti sklopljeni prije osnutka društva po osnutku i stjecanju pravne osobnosti društvo mora ratificirati. Ne ratificira li društvo takav pravni posao odnosno ne bude li društvo osnovano, obveze iz toga posla ne mogu se utužiti prema društvu. Tada za nastalu štetu odnosno za ispunjenje obveze iz takvih poslova drugoj ugovornoj strani odgovora osoba koja je sklopila takav posao u ime, odnosno za račun društva (engl. promoter). Drugim riječima, ako nije drukčije ugovoreno samim poslom, takva se osoba smatra jamcem trećoj osobi za ispunjenje obveze iz takva ugovora. ${ }^{21}$ Ratificira li društvo takav posao nakon osnutka, takva ratifikacija djeluje retroaktivno odnosno društvo koje je ratificiralo takav posao smatra se ugovornom stranom toga posla od trenutka sklapanja ugovora.

\subsubsection{Ujedinjeno Kraljevstvo}

I Ujedinjeno Kraljevstvo se nalazi na samom vrhu corporate friendly environment država. ${ }^{22}$ Engleski Companies Act iz 2006. godine (dalje: CA) tradicionalno se smatra izrazito liberalnim u usporedbi s nešto rigidnijim rješenjima država germanskoga pravnog kruga. Mnogim državama englesko pravo služilo je stoga kao uzor pri izgradnji svojeg nacionalnog prava društava. To su ponajprije države koje pripadaju common law krugu država (npr. Australija, Novi Zeland i Malezija), ali je ograničen utjecaj, ponajprije djelovanjem regulatornog natjecanja između država članica, proširen i na države kontinentalnopravnog kruga (npr. Nizozemsku, Njemačku, Francusku). ${ }^{23}$ Englesko pravo poznaje više tipova društava (npr. public company limited by shares, private company limited by shares, partnership, limited partnership, company limited by guarantee). Od iznesenih pravnih oblika, hrvatskom društvu s ograničenom

20 Tako vidi odredbu čl. 46. NZCA.

21 Tako vidi odredbu čl. 183. st. 1. NZCA. Radi se o tzv. institutu warrantya za naknadu štete, a sud može na zahtjev treće strane naložiti osobi koja je sklopila takav posao, u ime odnosno za račun društva, ispunjenje obveze iz takvog ugovora ili odrediti neku drugu mjeru u korist treće osobe. Više o tome vidi Williams, G., New Zealand, Corporations and Partnerships, Supplement 5, May 2011, paras. 142-152.

22 Prema statističkim indikatorima Svjetske banke Ujedinjeno Kraljevstvo nalazi se na 6. mjestu u svijetu po lakoći obavljanja gospodarske djelatnosti (ease of doing business), društvo je moguće osnovati u pet dana (time required to start a business) pri čemu je potrebno poduzeti samo 4 radnje (start-up procedures to register a business). Više o tome na službenim statističkim stranicama Svjetske banke (http://data.worldbank.org/).

Niz. Burgerlijk Wetboek značajno je izmijenjen i dopunjen 1992. godine, a temelji se na Građanskom zakoniku iz 1838. godine (http://www.dutchcivillaw.com/civilcodegeneral.htm).

23 Tako je, primjerice, pod utjecajem regulatornog natjecanja u njemačko pravo ušao Unternehmergesellschaft, kao pojednostavljena verzija GmbH-a. Više o tom društvu vidi naredno poglavlje 2.2. Trenutno stanje hrvatskoga prava društava i de lege ferenda prijedlozi. Za primjer Francuske vidi poglavlje d) Francuska. 
odgovornošću odgovara private company limited by shares (dalje: LTD), a o kojem će stoga nadalje biti riječi sa stajališta osnivanja toga društva. Kako bi zadržao dominantnu poziciju na tržištu, engleski zakonodavac 2006. godine promijenio je dotadašnji zakonski okvir s ciljem dodatne deregulacije do tada postojećih rješenja engleskoga prava društava. Što se tiče osnivanja društava, neke promjene odrazile su se, izravno ili neizravno, na samo osnivanje LTD društva.

Osnivanje LTD društva moguće je učiniti online na web stranici registra (engl. Companies House). Takvo osnivanje moguće je učiniti samo uz primjenu modela pravila društvenog ugovora (engl. model Articles of Association), kao temeljnog akta društva, te popunjavanje online prijave koja sadrži osnovne podatke o samom društvu, primjerice, podatke o sjedištu društva, informacije o tomu primjenjuju li se model pravila društvenog ugovora, informacije o imenovanim direktorima (engl. directors) $i$ tajnicima društva (engl. company secretary), podatci o iznosu uplaćenog temeljnoga kapitala ako ga društvo ima te informacije o osnivačima i njihovim udjelima u društvu. Model pravila društvenog ugovora primjenjuju se na sva društva koja neko pitanje nisu uredila drukčije svojim društvenim ugovorom ili pri registraciji uopće nisu podnijela društveni ugovor. ${ }^{24}$ Osim toga, potrebno je sastaviti i ugovor o osnivanju društva (engl. Memorandum of Association) kojim osnivači očituju svoju volju na osnivanje društva i pristaju biti njegovi članovi. ${ }^{25}$ Takav ugovor biva automatski generiran iz podataka danih u samoj prijavi pri registraciji (imena osnivača) kada je prijava osnivanja učinjena online. Prijavu nije potrebno ovjeriti kod javnog bilježnika niti naknadno potvrditi vlastoručnim potpisima osnivača odnosno direktora društva. Umjesto potpisa, radi verifikacije istinitosti prijave za osnivanje društva potrebno je, primjerice, unijeti mjesto rođenja, zadnje tri brojke telefonskog broja, zadnja tri broja putovnice, djevojačko prezime majke i ime oca svakog osnivača društva. Naknada za takvo osnivanje iznosi 15 funti, a plativa je na više načina (npr. bankovnom karticom ili putem paypal servisa). Po podnošenju uredne prijave društvo će u pravilu biti registrirano u roku od 24 sata. Osnivanje društva moguće je također učiniti slanjem popunjenih i vlastoručno potpisanih obrazaca (IN01) registracijskom tijelu. Trošak takve prijave iznosi 40 funti pri čemu se društvo registrira u roku od osam do deset dana od primitka uredne prijave. Plati li se pristojba od 100 funti društvo će biti registrirano istoga dana po primitku uredne prijave ako je prijava podnesena do 15 sati registracijskom tijelu. Osim izravno, moguće je kupiti već osnovano društvo (tzv. offthe-shelf company), no kako je postupak osnivanja značajno pojednostavljen i učinjen pristupačnijim, takva kupovina čini se sve manje svrsishodnom u poslovnoj praksi.

Pritom valja također naglasiti kako za LTD nije određen minimalan iznos temeljnoga kapitala, no kako društvo mora imati barem jednog osnivača koji ima barem jedan udio u društvu, na ime takvog udjela potrebno je uplatiti nekakav temeljni kapital (npr. jednu funtu). S druge strane, minimalni iznos temeljnoga kapitala za public company limited by shares, koji odgovara dioničkom društvu u hrvatskom pravu, iznosi 50 tisuća funti. ${ }^{26}$ Osim toga, LTD više ne mora imati imenovanu osobu

24 Tako vidi odredbu čl. 20. st. 1. CA.

25 Tako vidi odredbu čl. 8. CA.

26 Tako vidi odredbu čl. 763. st. 1. CA. Više o tome vidi Pettet, B., United Kingdom, Corporations 
koja će djelovati kao tajnik društva što pridonosi smanjenju troškova društva i olakšavanju njegova poslovanja jer se ovlasti tajnika prebacuju na direktore društva. ${ }^{27}$

Pored iznesenih promjena vezano uz osnivanje društva, 2006. godine englesko pravo društva izmijenjeno je i u drugim pogledima. Tako je, primjerice, zakonodavac izričito podržao elektroničku komunikaciju u unutarnjim odnosima u društvu, dakle između organa društva kao i između organa društva i članova tog društva. ${ }^{28}$ Pored toga, ukinuta je zabrana o davanju zajma društva za stjecanje udjela u tom društvu, ali i potreba pribavljanja odobrenja suda za smanjenje temeljnoga kapitala društva, a omogućena je i renominacija vrijednosti temeljnoga kapitala iz jedne valute u drugu valutu. ${ }^{29}$

\subsubsection{Nizozemska}

Nizozemska je nedavnim izmjenama i dopunama propisa koji uređuju pravo društava dospjela na visoko mjesto corporate friendly environment država. ${ }^{30}$ Konkretno, izmijenjena je i dopunjena Druga knjiga Građanskog zakonika (dalje: BW) čime je znatno reformirano dotadašnje pravo društava. ${ }^{31}$ Nizozemsko pravo poznaje više tipova društava (npr. naamloze vennootschap, besloten vennootschap, maatschap, vennootschap onder firma, commanditaire vennootschap). Od iznesenih, hrvatskom društvu s ograničenom odgovornošću najviše odgovara besloten vennootschap (dalje: BV), a o kojem će stoga nadalje biti riječi sa stajališta osnivanja društva.

Po uzoru na druge države kontinentalnog prava (npr. Francusku), nizozemski zakonodavac poduzeo je takvu značajnu reformu radi liberalizacije svojeg nacionalnog prava društva. Takva liberalizacija poslužila je kao odgovor na regulatorno natjecanje među državama članicama. ${ }^{32}$ Predmetna reforma bila je ponajviše usmjerena na BV, kao jedno od najučestalijih društava kapitala u Nizozemskoj. U tom pogledu, nizozemski zakonodavac uveo je reforme kao što je ukidanje minimalnog iznosa temeljnoga kapitala, uspostava novih pravila kontrole iznošenja kapitala iz društva, uvođenje novih vrsta članskih udjela u društvu i olakšavanje pravila vezanih uz prijenos takvih udjela na treće osobe.

and Partnerships, Supplement 13, December 1995, para. 131.

27 Tako vidi odredbu čl. 270. CA.

28 Tako, primjerice, vidi odredbe čl. 298., čl. 308., čl. 333. i čl. 360A. CA o mogućnosti održavanja skupštine članova elektroničkim putem, što uključuje i odašiljanje poziva elektroničkim putem. Posljednja odredba unesena je CA dopunama iz 2009. godine.

29 Tako za zajam društva za stjecanje udjela u tom društvu vidi odredbu čl. 682. CA, za isključenje potrebe prethodnog pribavljanja odobrenja suda pri smanjenju temeljnog kapitala, vidi odredbu čl. 641. CA, a za renominaciju temeljnoga kapitala, vidi odredbu čl. 622. CA.

30 Prema statističkim indikatorima Svjetske banke Nizozemska nalazi se na 28. mjestu u svijetu po lakoći obavljanja gospodarske djelatnosti (ease of doing business), društvo je moguće osnovati $\mathrm{u}$ četiri dana (time required to start a business), pri čemu je potrebno poduzeti samo četiri radnje (start-up procedures to register a business). Više o tome na službenim statističkim stranicama Svjetske banke (http://data.worldbank.org/).

31 Niz. Burgerlijk Wetboek značajno je izmijenjen i dopunjen 1992. godine, a temelji se na Građanskom zakoniku iz 1838. godine (http://www.dutchcivillaw.com/civilcodegeneral.htm).

32 U tom smjeru vidi Vliet, L., The Netherlands - New Developments in Dutch Company Law: The „Flexible“ Close Corporation, Journal of Civil Law Studies, Vol. 7, Issue 1, str. 272. 
Najznačajnija od svih iznesenih reformi odnosi se na ukidanje minimalnog iznosa temeljnoga kapitala po uzoru na neke common law države (npr. UK, Novi Zeland), ali i kontinentalnog pravnog sustava (npr. francuski SARL i SAS). Do 2012. godine minimalni iznos temeljnoga kapitala pri osnivanju BV iznosio je 18 tisuća eura. Izmjenama i dopunama ukinut je minimalni iznos temeljnoga kapitala za BV, dok je za NV, društvo koje odgovara dioničkom društvu u hrvatskom pravu, zadržan minimalni iznos temeljnoga kapitala od 45 tisuća eura. ${ }^{33}$ To ne znači kako osnivači BV-a ne mogu učiniti uplate za udjele koje stječu u društvu, a na ime uplate temeljnog ili vlastitog kapitala društva, već samo kako je isključivo na njima hoće li takve uplate učiniti ili ne. Pritom valja također naglasiti kako je uplate u novcu tada moguće učiniti u bilo kojoj valuti. ${ }^{34}$

Ukidanjem minimalnog iznosa temeljnoga kapitala za BV bitno je izmijenjen dotadašnji koncept društava kapitala koji se u velikoj mjeri oslanjao na temeljni kapital kao sredstvo zaštite vjerovnika. Takvo ukidanje, kao sredstva zaštite vjerovnika, pratilo je i ukidanje odnosno olakšavanje cijelog niza pratećih zaštitnih, a redovito i otegotnih, pravila kojima se imovina društva, unesena u društvo s naslova uplate temeljnoga kapitala, štitila od potencijalnih zlouporaba (npr. od njezina neunošenja $\mathrm{u}$ društvo odnosno naknadnog iznošenja takve imovine iz društva). ${ }^{35} \mathrm{~S}$ druge strane, kako više nisu bili „zaštićeni“ kategorijom temeljnoga kapitala, vjerovnike je bilo potrebno zaštititi na drugi način. Tako su postavljene dvije razine kontrole zaštite imovine društva, test pozitivne bilance (engl. balance-sheet test) i test sposobnosti podmirenja dospjelih i utuživih potraživanja u roku (engl. payment test). Prema prvom testu, glavna skupština društva može donijeti odluku o isplati dividende samo u pogledu dobiti koja bude ostvarena, a pod pretpostavkom da ukupna imovina društva prelazi zakonske i statutarne rezerve. ${ }^{36}$ Prema drugom testu, isplata dividende s naslova tako donesene odluke moguća je samo uz suglasnost poslovodnog organa društva. Takvu je suglasnost taj organ dužan uskratiti ako mu je poznato ili mu je trebalo biti poznato kako društvo, nakon isplate takve dobiti, neće biti u stanju uredno podmiriti dospjela i utuživa potraživanja vjerovnicima društva. ${ }^{37}$ Povrijede li takvu dužnost, članovi poslovodnog organa (direktori), a koji su znali ili morali znati kako društvo neće moći uredno podmirivati svoje obveze vjerovnicima društva u trenutku isplate dobiti, odgovaraju društvu solidarno i neograničeno za deficit koji je nastao zbog takve isplate. Do visine dobivene isplate tako odgovaraju i osobe koje su znale ili morale znati kako društvo, nakon isplate takve dobiti, neće biti u stanju uredno

33 Tako za NV vidi odredbu čl. 2:67. BW). Općenito o ukidanju temeljnoga kapitala za BV vidi Vliet, L., The Netherlands - New Developments in Dutch Company Law: The „Flexible“ Close Corporation, Journal of Civil Law Studies, Vol. 7, Issue 1, str. 276-277.

34 Tako vidi odredbu čl. 2:178. st. 2. BW.

35 Takvo je, primjerice, pravilo o potrebi procjene vrijednosti uloga s naslova uplate temeljnog kapitala revizora kada se radi o nenovčanim uplatama (čl. 2:204a. BW, čl. 2:204b. BW), pravilo o nastavku osnivanja društva (čl. 2:204c. BW) i pravilo o zaštiti vjerovnika pri smanjenju temeljnoga kapitala (čl. 2:208. BW).

36 Tako vidi odredbu čl. 2:216. st. 1. BW.

37 Tako vidi odredbu čl. 2:216. st. 2. BW. 
podmiriti dospjela i utuživa potraživanja vjerovnicima društva. ${ }^{38}$

Pored ukidanja minimalnog iznosa temeljnoga kapitala, još tijekom 2011. godine ukinuto je i odobrenje vlade kao preduvjet za osnivanje društva. Bez takvog odobrenja nije bilo moguće osnovati društvo, a njegovo izdavanje moglo se odbiti samo ako su odredbe temeljnog ugovora društva bile protivne zakonu, odnosno ako su bile protivne javnom moralu. Takav je sustav zamijenjen sustavom trajne kontrole nadležnog ministarstva. ${ }^{39}$ Osim toga, u nizozemskom pravu društava učinjene su i druge promjene, no one se izravno ne odnose na osnivanje društava. Tako su liberalizirane mogućnosti koje se odnose na članska prava koja se vežu uz udjele u društvu. Primjerice, mogu se izdati udjeli bez prava glasa, udjeli s višestrukim ili ograničenim pravom glasa, udjeli s ograničenim imovinskim pravima, udjeli koji imatelja obvezuju na dodatne činidbe prema društvu, a i udjeli koji nisu vinkulirani. ${ }^{40}$

\subsubsection{Francuska}

Francuska je jedna od prvih država članica EU-a koja se upustila u značajniju liberalizaciju svojeg prava društava. Takva liberalizacija pridonijela je lakoći obavljanja gospodarske djelatnosti u Francuskoj kao i izgradnji corporate friendly environment sredine. ${ }^{41}$ Kao i druge države članice, francusko pravo poznaje više tipova društava (npr. Société Anonyme, Société á Responsabilité Limitée, Société par Actions simplifiée). Od iznesenih, hrvatskom društvu s ograničenom odgovornošću najviše odgovara Société Anonyme, Société á Responsabilité Limitée (dalje: SARL), no svakako valja spomenuti i Société par Actions simplifiée (dalje: SAS) o kojima će nadalje biti riječi sa stajališta osnivanja društva. ${ }^{42}$

Francusko pravo društava uređuje Trgovački zakonik (dalje: CdC), a koji je značajno izmijenjen 1999., 2001., 2003. godine, a potom i nedavne 2008., 2009. te 2014. godine. ${ }^{43}$ Tako je izmjenama iz 2003. godine za SARL uklonjen minimalni iznos temeljnoga kapitala koji je prethodno iznosio 7,5 tisuća eura. ${ }^{44}$ Pritom barem petina

38 Tako vidi odredbu čl. 2:216. st. 3. BW.

39 Više o tome vidi Vliet, L., The Netherlands - New Developments in Dutch Company Law: The „Flexible“ Close Corporation, Journal of Civil Law Studies, Vol. 7, Issue 1, str. 275-276; Eisma, S., de Kluver, H., Netherlands, Corporations and Partnerships, Supplement 32, April 2002, paras. 62-63.

40 Tako, primjerice, vidi odredbu čl. 2:216. st. 7. BW o udjelima s ograničenim imovinskim pravom sudjelovanja u podjeli dobiti i odredbu čl. 2:228. st. 5. BW o udjelima bez prava glasa na skupštini društva. Više o tome, vidi Vliet, L., The Netherlands - New Developments in Dutch Company Law: The „Flexible“ Close Corporation, Journal of Civil Law Studies, Vol. 7, Issue 1, str. 278-281.

41 Prema statističkim indikatorima Svjetske banke Francuska nalazi se na 27. mjestu u svijetu po lakoći obavljanja gospodarske djelatnosti (ease of doing business), društvo je moguće osnovati $\mathrm{u}$ četiri dana (time required to start a business), pri čemu je potrebno poduzeti samo pet radnji (start-up procedures to register a business). Više o tome na službenim statističkim stranicama Svjetske banke (http://data.worldbank.org/).

42 Dok SARL odgovara društvu s ograničenom odgovornošću, SAS se smatra pojednostavljenim oblikom dioničkog društva.

43 Fra. Code de commerce iz 1807. godine (https://www.legifrance.gouv.fr/).

44 Tako vidi odredbu čl. 223-2. CdC. 
novčanog iznosa uloga mora biti plaćena pri osnivanju društva, dok se ulozi u stvarima i pravima moraju uplatiti u potpunosti. ${ }^{45}$ Osim u novcu, stvarima i pravima, uloge je moguće upisati ulaganjem vlastitog rada i činjenjem drugih usluga. ${ }^{46} \mathrm{U}$ pogledu prava društava, posebno je zanimljivo uređenje SAS koje se smatra pojednostavljenim oblikom francuskoga dioničkog društva - Société Anonyme. Tako je 2008. godine ukinut minimalni iznos temeljnoga kapitala potreban za osnivanje društva čime je uklonjen zahtjev prvotnog minimalnog iznosa temeljnoga kapitala od 37 tisuća eura. ${ }^{47}$ S druge strane, izmjenama iz 1999. godine određeno je kako je za osnivanje SAS-a dovoljna jedna fizička ili pravna osoba ${ }^{48} \mathrm{U}$ odnosu na sve ostalo, na odgovarajući se način primjenjuju pravila koja vrijede za Société Anonyme (dalje: SA) koje ima osobine dioničkog društva u hrvatskom pravu. Imajući u vidu strogost režima kojim se uređuje SA, kao oblik javnog društva kapitala, valjano se nameće pitanje je li takvim izmjenama SAS, kao oblik privatnog društva kapitala, odgovarajuće liberaliziran u odnosu na SA. Primjerice, tako se za unos uloga u SAS primjenjuju pravila koja vrijede za SA (npr. utvrđivanje vrijednosti nenovčanog uloga u društvo, postupak unosa uloga u društvo). ${ }^{49}$

Pored ovih izmjena koje se neposredno tiču samog osnivanja SARL i SAS, neke su izmjene učinjene i na drugim područjima. Tako su ublažena pravila o reviziji financijskih izvještaja SAS i SARL društva. Konkretno, članovi više nisu dužni imenovati vanjskog revizora, osim ako se ne ispune dva od tri zakonom predviđena uvjeta (na kraju poslovne godine vrijednost imovine društva bude veća od milijun eura za SAS odnosno milijun i pol eura za SARL, prihodi društva budu veći od dva milijuna eura za SAS odnosno tri milijuna i sto tisuća eura za SARL, društvo ima više od 20 zaposlenika za SAS odnosno 50 zaposlenika za SARL). ${ }^{50}$ Zatim, 2009. godine SAS može, radi trgovanja, uvrstiti svoje udjele i obveznice na multilateralnu trgovinsku platformu, a od 2014. godine kapital može prikupiti i ponudom udjela kroz sustave crowdfundinga na internetu, ali ne i putem uređenog tržišta kapitala. ${ }^{51}$

\subsection{Trenutno stanje hrvatskoga prava društava i de lege ferenda prijedlozi}

Kao odgovor na regulatorno natjecanje između država članica 2012. godine u hrvatsko pravo društava uvedeno je jednostavno društvo s ograničenom odgovornošću (dalje: JDOO). ${ }^{52}$ Takvo društvo koncipirano je po uzoru na njemačko društvo Unternehmergesellschaft (dalje: UG). Kao i u njemačkom pravu, temelji

45 Tako vidi odredbu čl. 223-7. st. 1. CdC.

46 Tako vidi odredbu čl. 223-7. st. 2. CdC.

47 Tako vidi odredbu čl. 227-1. st. 3. CdC.

48 Tako vidi odredbu čl. 227-1. st. 1. CdC.

49 Tako, primjerice, vidi odredbu čl. 227-1. st. 3. i st. 5. CdC.

50 Tako za SAS vidi odredbu čl. 227-9-1. st. 1. i st. 2. CdC, a za SARL odredbu čl. 223-35. st. 2. CdC.

51 Tako vidi odredbu čl. 227-1. st. 3. CdC.

52 Tako vidi Prijedlog zakona o izmjenama i dopunama Zakona o trgovačkim društvima, s Konačnim prijedlogom zakona od 12. srpnja 2012. godine (http://edoc.sabor.hr/). 
se na društvu s ograničenom odgovornošću, no za razliku od njega karakterizira ga nešto pojednostavljen postupak osnivanja. Pojednostavljenje se ponajviše ogleda $u$ smanjenju minimalnog iznosa temeljnoga kapitala potrebnog za osnivanje tog društva, smanjenju troškova i manjim zahtjevima u pogledu dokumentacije koja je potrebna za osnivanje toga društva. Tako je minimalni iznos temeljnoga kapitala potrebnog za osnivanje društva smanjen na deset kuna pri čemu najniži nominalni iznos poslovnog udjela mora iznositi barem jednu kunu. ${ }^{53}$ Pored toga, smanjeni su troškovi osnivanja kod javnog bilježnika, a ukinuta je i potreba objave osnivanja društva u Narodnim novinama. ${ }^{54}$ Nešto je i pojednostavljena izrada dokumentacije za osnivanje društva uvođenjem unaprijed pripremljenog obrasca zapisnika o osnivanju kojeg sastavlja javni bilježnik. Takav obrazac zapravo zamjenjuje izjavu o osnivanju društva odnosno društveni ugovor, a vrijedi i kao popis članova društva i popis osoba ovlaštenih za vođenje poslova društva. ${ }^{55}$ Zapisnik na kraju potpisuju osnivači i osoba ovlaštena za zastupanje, a njihove potpise ovjerava javni bilježnik. Pripremljena dokumentacija tada se elektronički prosljeđuje nadležnom trgovačkom sudu. ${ }^{56}$

Iz iznesenoga proizlazi kako je uvođenje JDOO-a u hrvatsko pravo društava pridonijelo olakšavanju pokretanja obavljanja poslovne aktivnosti, no ne može se oteti potrebi da se pritom kritički ne analizira postojeće stanje radi eventualnog utvrđenja prostora za daljnje poboljšanje postojećih rješenja. Pritom nije na odmet za primijetiti kako je Hrvatska u 2015. godini na statističkim indikatorima Svjetske banke pala za jedno mjesto u odnosu na 2014. godinu, zbog čega je trenutno na 40. mjestu po lakoći obavljanja gospodarske djelatnosti (ease of doing business). Pritom je za osnivanje društva potrebno poduzeti sedam radnji (start-up procedures to register a business), a jedini pomak u odnosu na 2014. godinu učinjen je u pogledu vremena potrebnog za početak obavljanja poslovne aktivnosti koji iznosi 12 dana (time required to start a business). ${ }^{57}$

\section{- One stop shop usluga i online osnivanje}

Prostor za napredak svakako postoji, ponajprije u osnivanju tzv. one-stop shop

53 Vidi odredbu čl. 390.a st. 3. ZTD-a. Usporedbe radi, minimalni iznos temeljnog kapitala za osnivanje društva s ograničenom odgovornošću iznosi 20 tisuća kuna.

54 Tako trošak osnivanja kod javnog bilježnika iznosi oko 500 kuna zbog izrade i ovjere potrebne dokumentacije, dok trošak sudske pristojbe iznosi 30 kuna. Tako, primjerice, za trošak osnivanja kod javnog bilježnika vidi odredbu čl. 25.a Pravilnika o privremenoj javnobilježničkoj tarifi, a za trošak sudske pristojbe vidi tar. br. 26. Zakona o sudskim pristojbama. Usporedbe radi, trošak osnivanja društva $s$ ograničenom odgovornošću iznosi otprilike nekoliko tisuća kuna zbog većeg javnobilježničkog troška i viših sudskih pristojbi.

55 Tako vidi Barbić, J., Pravo društava, Knjiga druga, Društva kapitala, Svezak II., Društvo s ograničenom odgovornošću, Društvo za uzajamno osiguranje, Kreditna unija, Europsko društvo - Societas Europea (SE), 6. izd., str. 604. Usporedbe radi, sam postupak osnivanja društva s ograničenom odgovornošću neznatno je složeniji zbog nepostojanja zakonom određenih obrazaca koji sadržajno obuhvaćaju više dokumenta koje je potrebno izraditi pri osnivanju predmetnog društva. Unatoč tomu, samo vrijeme potrebno za osnivanje društva s ograničenom odgovornošću može biti jednako onom za osnivanje JDOO-a ako se uplate uloga vrše u novcu.

56 Tako vidi odredbu čl. 39. i čl. 40. Zakona o sudskom registru.

57 Više o tomu na službenim statističkim stranicama Svjetske banke (http://data.worldbank.org/). 
usluge za osnivanje trgovačkog društva. Prema postojećem stanju, osnivač društva mora poduzeti više radnji na više različitih lokacija kako bi osnovao društvo. Tako, primjerice, čak i osnivač koji želi osnovati JDOO mora alternirati između javnog bilježnika, poslovnice banke odnosno Financijske agencije, Državnog zavoda za statistiku, nadležne službe mirovinskog i zdravstvenog osiguranja te porezne uprave. Pri osnivanju drugih trgovačkih društava, situacija može biti i složenija zbog, primjerice, potrebe provedbe revizije osnivanja. Iz iznesenog se može zaključiti kako u Hrvatskoj nije uspostavljena one-stop shop usluga za osnivanje trgovačkog društva.

Shodno tomu, valja se upitatizašto sve radnje osnivanja društva nije moguće učiniti online kroz središnji automatizirani informacijski sustav koji povezuje različite službe (npr. poreznu upravu, službe mirovinskog i zdravstvenog osiguranja, banku, Državni zavod za statistiku). Takvo osnivanje valja omogućiti popunjavanjem jednostavnih i unaprijed pripremljenih obrazaca. Pritom, verifikaciju istinitosti i točnosti podataka valja učiniti na druge načine bez upotrebe usluga javnog bilježnika (npr. ovjera potpisa osnivača i direktora). ${ }^{58}$ To se može postići, primjerice, verifikacijom kroz sustav e-Građanin za fizičke osobe, korištenjem biometrijske tehnologije ili elektroničkog potpisa, navođenjem osobnih podataka osnivača odnosno direktora društva kao što je OIB, broj osobne iskaznice, datum i mjesto rođenja, adresa prebivališta i ime oca. ${ }^{59}$ Potencijalnu zlouporabu takvih podataka valja spriječiti strogim mjerama preventivne zaštite (kaznena i/ili prekršajna odgovornost, ništavost društva), a identitet uključenih osoba provjeriti (redovitim i/ili izvanrednom) ex ante kontrolom kako od strane nadležnih državnih tijela, tako i od strane trećih osoba (npr. vjerovnika društva). Pritom troškove osnivanja valja svesti na plaćanje paušalne sudske pristojbe (npr. iznosa od $30 \mathrm{kuna}$ ) upotrebom integriranog online servisa plaćanja. Alternativno ili kombinirajući s prethodnom metodom, nešto manje fleksibilno osnivanje društva može se postići poduzimanjem svih potrebnih radnji kod javnog bilježnika ili nekog drugog tijela (npr. ureda HITRO.HR) koji tada djeluje kao one-stop shop. Takvo tijelo tada po uputi osnivača sastavlja elektroničku prijavu popunjavanjem unaprijed pripremljenih

58 Ovdje valja upozoriti na prijedlog Direktive o društvu s ograničenom odgovornošću s jednim članom - Societas Unius Personae od 9. travnja 2014. godine, COM 2014/212 final. Tom se direktivom državama članicama predlaže uvođenje novog oblika društva koje posebice karakterizira osnivanje koje se provodi u potpunosti elektroničkim putem. Takvom prijedlogu usprotivile su se uglavnom države članice germanskoga kruga koje smatraju kako takvo elektroničko osnivanje ne može osigurati odgovarajuću mjeru sigurnosti utvrđivanja identiteta uključenih osoba. Pored pojedinih država članica, prijedlogu se oštro usprotivilo i udruženje javnih bilježnika Europe Notaries of Europe. Tako vidi Position of the Council of Notariats of the EU concerning the porposal for a Directive on the single-member private limited liability company (SUP) od 24. travnja 2014 (dostupno na: http://www.notaries-of-europe.eu/). Više o svemu vidi Petrović, S., Bilić, A., Kemec Kokot, I., Provjera identiteta jedinog člana prema Prijedlogu Direktive o Societas Unius Personae, Hrvatska pravna revija, lipanj 2015., str. 1827.

59 Sustav e-Građanin mogao bi se urediti na način da po podnošenju prijave za osnivanje svakom osnivaču i direktoru navedenom u takvoj prijavi dođe kroz takav sustav zahtjev za potvrdom sudjelovanja u postupku osnivanja (npr. kao osnivač društva). Takvu potvrdu moguće je dati elektronički samo uz korištenje vjerodajnice visokog stupnja sigurnosti (npr. elektroničke osobne iskaznice), a do davanja takve potvrde svih uključenih nije moguće provesti upis $u$ sudski registar jer prijava nije potpuna. 
obrazaca. Za pretpostaviti je kako će takvo osnivanje ublažiti neke dvojbe glede zlouporabe identiteta jer će se pri osnivanju provjeriti identiteti svih uključenih osoba (osnivača i direktora). No, izgledno je i kako će takvo osnivanje biti skuplje zbog potrebe plaćanja pristojbe odnosno naknade za tako pružene usluge. U svakom slučaju, trošak osnivanja valja maksimalno umanjiti posebice kada se radi o društvu s malim iznosima temeljnoga kapitala. Pretpostavlja se kako je osnivanje društva putem jedne osobe koja djeluje kao one-stop shop već u velikoj mjeri izvedivo kroz sustav e-Tvrtke, jer javni bilježnik sam ili zajedno s uredom HITRO.HR već elektronički prosljeđuju prijave osnivanja i prateću dokumentaciju nadležnom trgovačkom sudu radi upisa osnivanja ${ }^{60} \mathrm{Za}$ očekivati je i kako bi takvo sustavno rješenje omogućilo pokretanje obavljanja poslovne aktivnosti pod okriljem pravne osobnosti društva u roku od 24 sata po podnošenju uredne prijave ${ }^{61}$ Pritom valja ukloniti ili barem krajnje umanjiti broj naknadnih prijava nadležnim državnim tijelima automatizacijom takvih prijava kroz središnji informacijski sustav (npr. prijava osnivanja društva nadležnoj poreznoj upravi i prijava poslovnog subjekta Državnom zavodu za statistiku).

\section{- Društvo kapitala bez minimalnog iznosa temeljnoga kapitala}

Osim samoga postupka osnivanja, nameće se i pitanje opravdanosti zahtjeva minimalnog iznosa temeljnoga kapitala kojeg je potrebno uplatiti pri osnivanju društva. Za JDOO tako je potrebno uplatiti deset kuna na ime temeljnoga kapitala društva, a za društvo s ograničenom odgovornošću 20 tisuća kuna. ${ }^{62}$ Iako se, doduše, ne radi o visokim iznosima temeljnog kapitala, u usporedbi s drugim državama germanskoga pravnog kruga nameće se pitanje značaja uplate visokih iznosa na ime temeljnog kapitala društva u suvremenom pravu društava. ${ }^{63}$ Zastarjelo je stajalište o temeljnom kapitalu kao garancijskom kapitalu kojim se štite vjerovnici društva jer to što društvo ima određeni iznos temeljnoga kapitala ne znači kako ono u tom iznosu može namiriti potraživanja vjerovnika. Ono je samo znak kako je u određenom trenutku određena imovina unesena $u$ društvo na ime uplate temeljnog uloga $u$ društvo odnosno kako društvo prema članu društva ima određeno potraživanje $\mathrm{s}$ naslova uplate takvog uloga u društvo ako on ranije nije bio uplaćen. ${ }^{64}$ Kako je

60 Tako vidi odredbe čl. 39. st. 1. i čl. 40. st. 3. Zakona o sudskom registru. Za primjenu sustava e-Tvrtka na upis osnivanja društva s ograničenom odgovornošću vidi odredbu čl. 58. Zakona o sudskom registru.

61 Odredbom čl. 62. st. 2. Pravilnika o načinu upisa u sudski registar određeno kako je sudski registar dužan u roku 24 sata po urednoj elektroničkoj prijavi kroz sustav e-Tvrtka dostaviti rješenje o upisu u sudski registar. Takvo rješenje ne znači kako poslovni subjekt pod okriljem vlastite pravne osobnosti može odmah početi obavljati poslovnu djelatnost jer je nakon toga potrebno izvršiti odgovarajuće prijave i drugim državnim tijelima (npr. prijava poreznoj upravi, prijava u mirovinsko i zdravstveno osiguranje, izrada pečata, otvaranje bankovnog računa, prijava u Državni zavod za statistiku). Tek kada su poduzete i te dodatne radnje, društvo može početi s normalnim obavljanjem poslovne aktivnosti.

62 Tako vidi odredbu čl. 389. st. 2. i odredbu čl. 390.a st. 3. ZTD-a.

63 Tako je, primjerice, minimalni iznos temeljnoga kapitala za njemački GmbH 25 tisuća eura, za njemački UG 1 euro, za austrijski GmbH 35 tisuća eura, a za švicarski SARL 20 tisuća franaka.

64 Tako vidi Barbić, J., Pravo društava, Knjiga druga, Društva kapitala, Svezak I., Dioničko društvo, 6. izd., str. 46. 
uvođenjem JDOO-a u hrvatsko pravo društava minimalni iznos temeljnoga kapitala smanjen na deset kuna opravdano se dovodi u dvojbu potreba postojanja instituta minimalnog iznosa temeljnoga kapitala kod društva s ograničenom odgovornošću. ${ }^{65}$ Drugim riječima, minimalni iznos temeljnoga kapitala valjalo bi ukinuti te prepustiti osnivačima da sami odrede visinu temeljnoga kapitala društva što znači kako takav kapital, primjerice, može iznositi i jednu kunu. Ukidanje toga pravila može dovesti do olakšavanja odnosno do ukidanja cijelog niza pravila kojima se štiti unos odnosno održava temeljni kapital u društvu (npr. pravila o nastavku osnivanja), a što će pridonijeti pojednostavljenju cijelog sustava prava društava. $\mathrm{S}$ druge strane, $\mathrm{u}$ tom slučaju imovinu društva valjalo bi odgovarajuće zaštititi od potencijalnih zlouporaba na štetu vjerovnika i samog društva uspostavom novih zaštitnih pravila (npr. pravila o testu sposobnosti podmirenja dospjelih i utuživih potraživanja u roku tzv. payment test). ${ }^{66}$ To ne znači nužno ukidanje samog instituta temeljnoga kapitala jer ta pravna kategorija ima iznimnu važnost u uređenju odnosa u društvima kapitala (npr. pri određivanju omjera sudjelovanja člana u podjeli dobiti društva). ${ }^{67}$ Ukidanje kategorije minimalnog iznosa temeljnoga kapitala ne sprječava članove da društvu osiguraju imovinu za obavljanje poslovne aktivnosti na druge načine, a ni da nakon osnivanja povećaju temeljni kapital društva.

Pritom valja naglasiti kako je JDOO zamišljen kao podvrsta društva s ograničenom odgovornošću odnosno kao prijelazni oblik prema tom ,pravom“ društvu $\mathrm{s}$ ograničenom odgovornošću. ${ }^{68}$ To je vidljivo iz toga što povećanjem temeljnoga kapitala na iznos od 20 tisuća kuna ili više JDOO postaje društvo s ograničenom odgovornošću. ${ }^{69}$ Osim toga, zakonodavac je za JDOO propisao određena ograničenja

65 Ukidanje minimalnog iznosa temeljnoga kapitala za dioničko društva nije moguće zbog zahtjeva Druge direktive Vijeća od 13. prosinca 1976. godine, 77/91/EEZ, OJ L 26, 31.1.1977. Unatoč takvom rješenju, iz prethodno iznesenih razloga nema razumnog opravdanja ni za zadržavanje kategorije minimalnog iznosa temeljnoga kapitala za dionička društva, time više što on iznosi 200 tisuća kuna.

66 Taj se test, primjerice, primjenjuje u Nizozemskoj. Druga strana tog testa tzv. test pozitivne bilance već je na snazi u hrvatskom pravu društava. Tako odredba čl. 220. st. 7. ZTD-a određuje kako dividenda koja se isplaćuje dioničarima ne smije biti veća od iznosa dobiti iskazane u godišnjem financijskom izvješću za posljednju poslovnu godinu uvećanu za zadržanu dobit iz prethodnih godina i sredstva rezervi koje se mogu koristiti za takve isplate dioničarima, a koji je umanjen za gubitke iz ranijih poslovnih godina te iznose koji su po zakonu ili statutu uneseni u rezerve društva.

67 Uloga temeljnoga kapitala ključna je u državama kontinentalnog pravnog kruga, a i u nekim common law državama, no u praksi su se pojavile države koje su bitno umanjile njegovu ulogu i značaj u sustavu prava društava (npr. Novi Zeland). Tako, primjerice, odredba čl. 46A. NZCA određuje kako pri osnivanju društva članovi nisu dužni izvršiti plaćanje ili ispuniti neku drugu protučinidbu društvu na ime udjela koje stječu u društvu, osim ako takva obveza ne proizlazi iz temeljnog ugovora društva ili ugovora koji je sklopljen prije kao i nakon upisa tog društva u sudski registar. U tom smjeru vidi i odredbu čl. 38. NZCA prema kojoj udio u društvu ne smije imati nominalnu ili par value naznaku vrijednosti.

68 U tom smjeru vidi Barbić, J., Pravo društava, Knjiga druga, Društva kapitala, Svezak II., Društvo s ograničenom odgovornošću, Društvo za uzajamno osiguranje, Kreditna unija, Europsko društvo - Societas Europea (SE), 6. izd., str. 598. 
pa tako, primjerice, ono može imati najviše tri člana i jednog člana uprave, ne može imati ni nadzorni odbor, a ulozi se mogu uplatiti samo u novcu, a i stroži je režim popunjavanja zakonskih rezervi nego što je to kod društva s ograničenom odgovornošću..$^{70}$ Pretpostavlja se kako su iznesena ograničenja učinjena iz praktičnih razloga olakšavanja i ubrzanja postupka osnivanja društva te uspostave prisilnog mehanizma za što bržim preoblikovanjem takvih društava u tradicionalno društvo s ograničenom odgovornošću koje ne poznaje takva ograničenja. Radi olakšavanja sustava hrvatskoga prava društava JDOO bi kao pravni oblik valjalo ukinuti, a načelo pojednostavljenog osnivanja toga društva odgovarajuće preslikati na društvo s ograničenom odgovornošću koje ne bi imalo određeni minimalni iznos temeljnoga kapitala. Pritom, pojednostavljeno osnivanje valja primijeniti samo na osnivanje društava na koja se primjenjuju dispozitivna rješenja zakona. Žele li članovi izmijeniti neko od dispozitivnih rješenja (npr. pravilo o pravu glasa u skupštini ili o nepostojanju nadzornog odbora) neće biti moguće primijeniti unaprijed pripremljene obrasce, jer će morati sklopiti poseban društveni ugovor što može dovesti do povećanja troškova, a i produljenja trajanja postupka osnivanja društva. Isti učinak vjerojatno ima i tzv. kvalificirano osnivanje odnosno unos stvari i prava na ime uplate temeljnoga kapitala društva. Nakon osnivanja ništa ne smije priječiti članove društva da izmijene neko od dispozitivnih rješenja društvenog ugovora ili naknadno povećaju temeljni kapital unosom stvari i/ili prava u društvo.

\section{- Izjava osnivača o tomu da nisu porezni dužnici}

Sporan je uvjet davanja izjave osnivača o nepostojanju nepodmirenih dugovanja na osnovi poreza, doprinosa za mirovinsko odnosno zdravstveno osiguranje kao i dugovanja za neto plaće zaposlenicima. ${ }^{71}$ Takvu izjavu osnivači moraju priložiti prijavi za osnivanje društva, ona ne smije biti starija od 30 dana po podnošenju prijave, a mora sadržavati i popis svih subjekata upisa u kojima je osnivač član društva s udjelom koji predstavlja barem 5 posto udjela u temeljnom kapitalu društva ili glasačkim pravima, odnosno popis subjekta s udjelom koji osnivaču omogućuje ostvarenje značajnog utjecaja na upravljanje društvom. Davanjem takve izjave nastoji se spriječiti osnivanje društva osobi koja nije podmirila svoje obveze prema državi i zaposlenicima kao i osobi koja je član društva koje nije podmirilo takve obveze, a ponajprije radi sprječavanja potencijalnih zlouporaba na štetu ranijeg društva, a i stvaranja novih obveza koje osnivač potencijalno neće biti u stanju podmiriti. Praktično gledajući, davanje takve izjave vjerojatno je posljedica nedovoljne povezanosti različitih državnih službi koje bi same mogle vršiti takvu kontrolu, barem u pogledu domaćih društava. Neovisno o tomu, predmetna odredba znači kako osobe koje imaju nepodmirenih obveza prema državi i/ili zaposlenicima ili su članovi društava koji imaju takve obveze ne mogu osnovati društvo. Postojanje predmetnih okolnosti ne smije biti prepreka obavljanju gospodarske djelatnosti, bilo tuzemnih ili inozemnih osoba, tim više što je prag od 5 posto udjela u društvu i iznimno strogo postavljen. Pored toga, davanje takve izjave ponajprije znači davanje izjave o postojanju negativne činjenice što je samo po sebi

70 Tako vidi odredbu čl. 387. st. 2. i odredbu čl. 390.a ZTD-a.

71 Tako vidi odredbu čl. 40.a Zakona o sudskom registru. 
protivno pravilima o teretu dokazivanja, a zbog čega ne bi ni smjelo biti temeljem za osnivanje društva. Potom bi se moglo raspravljati i o ustavnosti takvog rješenja imajući u vidu pravila o poduzetničkoj i tržišnoj slobodi. Osnivanje društva ne treba uvjetovati davanjem predmetne izjave jer se njezinim davanjem pretpostavlja zlouporaba od strane osnivača što ne mora biti slučaj, a njezino davanje neosnovano privilegira određene kategorije vjerovnika (državu i zaposlenike) na štetu ostalih vjerovnika. Dvojbena je i može li postizanje svrhe koja se želi ostvariti davanjem takve izjave postići bez ograničavanja pristupa obavljanju gospodarske djelatnosti? Dođe li do zlouporabe, zaštita se uvijek može osigurati ad hoc primjenom postojećih pravnih sredstava. Odgovarajuću zaštitu tako je moguće postići primjenom drugih pravnih mehanizama kao što je, primjerice, pravilo o proboju pravne osobnosti (čl. 10. ZTD) ili pravilo o pobijanju pravnih radnji dužnika (čl. 66. Zakona o obveznim odnosima). U svakom slučaju, ako bi se nepostojanje takvih nepodmirenih dugovanja zadržalo kao uvjet za osnivanje društva, što se ne zagovara, kontrolu nepostojanja takvih dugovanja moguće je učiniti uvidom u odgovarajuće registre koje vode nadležne javne službe (npr. porezna služba i službe zdravstvenog i mirovinskog osiguranja). ${ }^{72}$

Konačno, u najmanjoj mjeri valja povećati prag $\mathrm{s}$ kojim osnivač sudjeluje $\mathrm{u}$ drugoj osobi na 25 posto članskih prava te produljiti rok valjanosti takve izjave s 30 dana na 60 dana. Prag od 25 posto odgovara kontrolnom pragu prema Zakonu o preuzimanju dioničkih društava, a rok od 30 dana na 60 dana valja produljiti zbog praktičnih poteškoća na koje nailaze strani ulagatelji koji nemaju tuzemno boravište, a za koje se isto traži davanje takve izjave. ${ }^{73}$

\section{- Uloga registarskog suda}

Problem predstavlja i u praksi utvrđeno neujednačeno djelovanje registarskog suda pri odlučivanju o prijavi za upis u sudski registar. Uloga registarskog suda valja svesti na prima facie provjeru ispunjenja zakonom određenih pretpostavki upisa $u$ sudski registar. Registarski sud stoga nikako ne smije provjeravati točnosti i istinitosti okolnosti navedenih u prijavi i njezinim prilozima, već se samo orijentirati na to jesu li ispunjene formalne pretpostavke upisa. Pritom se ipak stječe dojam kako su takve pretpostavke nedovoljno jasno određene zakonom. Tako, primjerice, odredba članka 43. stavka 3. točke 7. Zakona o sudskom registru određuje kako prijava za upis mora biti u suglasnosti s odredbama akta kojima se određeni podatci ili promjene upisuju u sudski registar. Prije toga predmetna odredba već određuje kako prijava mora imati propisani sadržaj i oblik, mora je podnijeti ovlaštena osoba i u odgovarajućem broju primjeraka, a isto valja primijeniti i na isprave koje se prilažu uz prijavu. ${ }^{74}$ Shodno

72 Radi li se o stranim fizičkim ili pravnim osobama, vršenje takvih uvida biti će otežano ili će biti u diskreciji nadležnog stranog tijela. No isto vrijedi i za postojeće stanje jer žele li tuzemna nadležna tijela provjeriti istinitosti dane izjave strane fizičke ili pravne osobe moraju opet kontaktirati nadležno inozemno tijelo.

73 Za kontrolni prag vidi odredbu čl. 5. st. 4. Zakona o preuzimanju dioničkih društava.

74 Nažalost, u primjeni odredbe čl. 43. Zakona o sudskom registru također se pokazalo kako registarski sudovi ne postupaju ujednačeno, a u praksi se pokazalo kako neki postupaju suprotno načelu jedinstvenosti i zakonitosti, ispitujući jesu li ispunjene i neke druge pretpostavke koje nisu određene zakonom. Više o tome vidi Barbić, J., Pravo društava, Knjiga prava, Opći dio, 3. 
tomu nameće se pitanje čemu dodatno naglašavanje kako sud može izvršiti upis u sudski registar samo ako je prijava u skladu s odredbama akta na temelju kojeg se vrši upis. To upućuje na zaključak kako je uz utvrđivanje postojanja prethodno iznesenih pretpostavki registarski sud također ovlašten materijalno tumačiti odredbe propisa na temelju kojih se vrši upis, a sve kako bi stekao uvjerenje kako je prijava u sadržajnom skladu s mjerodavnim odredbama toga propisa. Time se registarski sud ovlašćuje na tumačenje materijalnih odredaba propisa što predstavlja prekoračenje općeg pravila o razini ispitivanja pretpostavki za upis u sudski registar. Osim što takvo rješenje može rezultirati duljim vremenom potrebnim za donošenje odluke o upisu, ono može dovesti i do neujednačenosti u postupanju pojedinih registarskih sudova. $\mathrm{S}$ druge strane, potpuno je nepotrebna navođenje u t. 8. iste odredba zakona kako se prijava smatra osnovanom ako sadrži ,zahtjev s podacima za koje je propisano da se upisuju u registar", jer ranija t. 5. iste odredbe već određuje kako prijava mora imati propisani sadržaj. Drugim riječima, upis u sudski registar valja svesti samo na podnošenje prijave i njezinih priloga (npr. društveni ugovor) ovlaštene osobe, $u$ određenom sadržaju, obliku i u odgovarajućem broju primjeraka. Zahtjev t. 4. iste odredbe kako prateći prilozi moraju biti doneseni u propisanom postupku znači samo kako sud prima facie provjerava je li predmetnu ispravu donijela ovlaštena osoba u odgovarajućem postupku (npr. kako je društveni ugovor sklopljen od osnivača društva u obliku javnobilježničkog akta ili privatne isprave koju je potvrdio javni bilježnik). Drugim riječima, pri ispitivanju postojanja pretpostavki za upis u sudski registar registarski sud ne smije utvrđivati materijalnu valjanost sadržaja takvih priloga. Povrede u pogledu propisanog sadržaja takvih isprava mogu se sankcionirati u zasebnom postupku kada se ex ante utvrdi takva povreda.

Uspostavi li se takva prima facie kontrola prijave za upis valja razmisliti i o preustroju registarskih sudova tako da u prvom stupnju o upisu u registar ne odlučuju više registarski suci, već službenici i referenti odgovarajućeg zvanja i stručne spreme (npr. upravni pravnik), s odgovarajućim iskustvom u registarskim stvarima i položenim stručnim ispitom. Naime, svede li se registarski sud u prvom stupnju samo na prima facie provjeru postojanja pretpostavki za upis, nema potrebe da odluku o takvom upisu donose visokokvalificirani suci. Kada se odlučuje o registarskim stvarima, suce valja zadržati u drugom stupnju, kao jamce kontrole i pravne sigurnosti.

Zakon o sudskom registru predviđa mogućnost rezervacije tvrtke, no ne i mogućnost upisa društva u sudski registar ako se prijavljena tvrtka društva jasno ne razlikuje od tvrtke drugog društva upisanog u registru. ${ }^{75} \mathrm{U}$ takvim bi situacijama valjalo omogućiti upis društva u sudski registar pod tvrtkom koja odgovora matičnom broju toga subjekta upisa. Takvo rješenje pridonijelo bi brzini osnivanja, a članovi društva mogli bi odmah po upisu društva u sudski registar izmijeniti takvu tvrtku.

\section{- Sukcesivno osnivanje dioničkog društva}

Kada govorimo o osnivanju dioničkog društva, radi pojednostavljenja i deregulacije postojećega pravnog okvira valjalo bi ukinuti mogućnost sukcesivnog

izd., str. 544.

75 Za mogućnost rezervacije tvrtke vidi odredbe čl. 50.a do 50.c Zakona o sudskom registru. 
osnivanja za dionička društva. Sukcesivno osnivanje iznimno je rijetko u praksi jer traje duže, sa sobom povlači visoke troškove osnivanja (npr. trošak provedbe postupka javnog upisa dionica, trošak sazivanja i održavanja osnivačke skupštine), a i veliki rizik neuspjeha upisa društva zbog toga jer nisu upisane sve dionice društva ili zbog neuspjeha u održavanju osnivačke skupštine društva. ${ }^{76}$ Takvo osnivanje temelji se na omogućivanju prikupljanja većeg početnog kapitala društava iz vanjskih izvora odnosno od osoba koje nisu usvojile statut društva. Iako takav oblik osnivanja može biti važan pri osnivanju dioničkog društva koje se namjerava baviti djelatnošću za koju je potreban visok početan iznos temeljnog kapitala (npr. bankarsku djelatnost), ne postoji razlog zašto se takvo društvo ne bi moglo osnovati simultano uplatom minimalnog iznosa temeljnoga kapitala, a onda povećanjem temeljnoga kapitala povećati taj kapital na visinu koja je potrebna za obavljanje planirane djelatnosti. Po povećanju temeljnoga kapitala može se tražiti suglasnost nadležnog regulatora (npr. Hrvatske narodne banke za obavljanje bankarske djelatnosti), a po stjecanju takve suglasnosti i izvršiti odgovarajuću promjenu predmeta poslovanja društva u sudskom registru.

\section{- Predmet poslovanja}

Radi pojednostavljenja postojeće regulacije valja sagledati postojeće uređenje kategorije predmeta poslovanja društva. Zakonodavac već određuje kako trgovačka društva mogu obavljati svaku dopuštenu djelatnost pri čemu propisuje ograničenja samo za djelatnosti od posebnog društvenog interesa (npr. obavljanje bankarske djelatnosti, djelatnosti pružanja privatne zaštite, energetskih djelatnosti, djelatnosti gospodarenja otpadom). ${ }^{77}$ Ponajprije bi valjalo revidirati postojeća ograničenja te vidjeti je li suglasnost nadležnog tijela potrebna baš za svaku od tako reguliranih djelatnosti ili se broj takvih djelatnosti može smanjiti. ${ }^{78}$ To ne znači ukidanje regulacije djelatnosti od općeg društvenog interesa, već samo prebacivanje težišta na ex ante nadzor obavljanja takvih djelatnosti. Pored toga, valjalo bi bitno revidirati kategoriju predmeta poslovanja u sudskom registru. Ta kategorija služi samo kao informacija trećima, koji s trgovačkim društvom dolaze u doticaj, o tomu kakvom se djelatnošću

76 Tako vidi odredbe čl. 199. i čl. 204. ZTD-a.

77 Tako, primjerice, za općenito dopuštenje u pogledu slobode obavljanja gospodarske djelatnosti vidi odredbu čl. 32. st. 1. ZTD-a, a za ograničenja vidi odredbe čl. 32. st. 2. do st. 4. ZTD-a te odredbe čl. 34. st. 2. ZTD-a.

78 To je posebice izraženo na lokalnoj razini gdje se za redovito širok spektar jedne određene djelatnosti traži pribavljanje odgovarajuće suglasnosti gradskih i lokalnih vlasti kao što je, primjerice, djelatnost gospodarenja komunalnim otpadom. Tako je suglasnost potrebna i za prikupljanje i za skladištenje i obradu raznih kategorija otpada. Pritom nije jasno zašto uređenje djelatnosti prikupljanja otpada jednostavno ne prepustiti tržištu ili minimalnim uvjetima za obavljanje tih djelatnosti koji bi bili, primjerice, određeni javnim natječajem i naknadno sklopljenim ugovorom? Time se postiže barem isti, ako ne i bolji učinak, kao i uvjetom za pribavljanje prethodne suglasnosti za obavljanje tih djelatnosti nadležnog tijela, a svakako se pridonosi deregulaciji, olakšavanju birokracije i smanjenju raznih nameta koji nepotrebno opterećuju gospodarstvo, posebice stoga što su takve suglasnosti redovito vremenski ograničenog trajanja. 
ono bavi. ${ }^{79}$ Istu ulogu ima i tvrtka koja, uz naznaku koja pobliže obilježava ime i vrstu društva, sadržava i naznaku predmeta poslovanja. ${ }^{80}$ Drugim riječima, ako je zakonom već određena općenito sloboda izbora u obavljanju gospodarskih djelatnosti, a zainteresirane treće osobe mogu se iz tvrtke društva informirati o temeljnoj djelatnosti tog društva, nije jasno zbog čega se od društva zahtijeva izrada popisa djelatnosti kojima se ono namjerava baviti, a koje se upisuju u sudski registar. Izneseno rješenje dovelo je do toga da se u praksi navodi cijelo mnoštva raznih $\mathrm{i}$ redovito nepovezanih djelatnosti pod predmetnom kategorijom u sudskom registru. ${ }^{81}$ Takav popis djelatnosti, redovito sadrži djelatnosti kojima se gospodarski subjekt nikada nije bavio niti će se njima baviti jer se osnivačima u određivanju tih djelatnosti to činilo kao nešto čime bi se društvo jednoga dana moglo baviti. Štoviše, kada se gospodarska koncepcija društva promijeni i kada se donose odluka o obavljanju nekih novih djelatnosti koje ranije nisu upisane u sudski registar, ranije utvrđenom popisu redovito se samo dodaju, bez njihova brisanja te nove djelatnosti. Takva praksa pridonosi nepouzdanosti predmeta poslovanja kao pokazatelja djelatnosti koje društvo trenutno obavlja, a što je i temeljna funkcija te pravne kategorije. S druge strane, trećima takvo što može biti samo pokazatelj neozbiljnosti i nedostatka poduzetničke ideje. Ukidanje kategorije predmeta poslovanja ne bi imalo negativnih učinaka na postojeće stanje jer su, radi zaštite pravne sigurnosti, poslovi koje društvo sklopi izvan djelatnosti upisanih u sudski registar valjani. ${ }^{82} \mathrm{U}$ pogledu djelatnosti za čije je obavljanje potrebno prethodno pribaviti suglasnost nadležnog tijela, takve bi suglasnosti ipak valjalo podnijeti registarskom sudu radi upisa pod odgovarajuću kategoriju u sudskom registru, no nadzor nad obavljanjem takve djelatnosti u skladu s mjerodavnim propisima valja prepustiti isključivo nadležnom tijelu.

\section{- Pečat trgovačkog društva}

U hrvatskoj poslovnoj praksi gotovo da nema pravnog posla kod kojeg potpis ovlaštenog zastupnika trgovačkog društva ne prati i pečat društva. Korištenje pečata u domaćem pravnom prometu, kao anomalija, ušlo je u sve pore pravnog prometa iako za njegovo korištenje nema jasne pravne osnove. Tako, primjerice, niti Zakon o obveznim odnosima (dalje: ZOO) niti ZTD ne uvjetuje sklapanje pravnog posla stavljanjem pečata društva na ispravu ugovora. ${ }^{83}$ Potreba pečaćenja pravnog posla

79 Tako vidi Barbić, J., Pravo društava, Knjiga prava, Opći dio, 3. izd., str. 355.

80 Tako vidi odredbu čl. 13. ZTD-a. Ovdje valja naglasiti i kako prema odredbi čl. 12. ZTD-a podatci sadržani u tvrtki moraju biti istiniti. To, između ostalog, znači kako naznaka predmeta poslovanja u tvrtki mora odgovarati istini odnosno tako naznačena djelatnost mora biti djelatnost koju društvo redovito obavlja. Bude li u tvrtki naznačena djelatnost koju društvo više ne obavlja, bit će potrebno odgovarajuće izmijeniti tvrtku. Više o tome vidi Barbić, J., Pravo društava, Knjiga prava, Opći dio, 3. izd., str. 326-327.

81 Tako je u sudskom registru moguće naći društva, koja uz pružanje usluga informatičkog projektiranja, edukacije i prodaje računala, pružaju i ugostiteljske usluge, pedikerske usluge i slično.

82 Tako vidi odredbu čl. 35. st. 3. ZTD-a.

83 Tako, primjerice, vidi odredbe čl. 247. i 260. ZOO-a o sklapanju ugovora te odredbe čl. 21. st. 4. i st. 5. ZTD, čl. 241. st. 4. ZTD-a o upotrebi tvrtke i zastupanju dioničkog društva. Izneseno potvrđuje i domaća sudska praksa pa tako vidi presudu Visokog trgovačkog suda 1133/03 od 
u pravilu je proizvod domaće birokracije i zastarjele poslovne prakse i običaja. Tako brojni obrasci porezne uprave, drugih javnih servisa, ali i interni akti osoba koji pružaju usluge od javnog značaja (npr. kreditnih institucija) zahtijevaju da potpis ovlaštene osobe za zastupanje prati i pečat zastupane pravne osobe.$^{84}$ Tako se u domaćem pravnom prometu duboko ukorijenila praksa oslanjanja na pečat kao sredstvo potvrde identiteta podnositelja zahtjeva umjesto da se potvrda, primjerice kada je riječ o javnim službama, učini kroz središnji informacijski sustav provjerom ovlaštenja u sudskom registru. Pečat kao sredstvo potvrde takvog ovlaštenja nije jamac sigurnosti jer se pečati danas mogu lako krivotvoriti. Shodno tomu, nameće se pitanje čemu ustrajanje na takvoj nepotrebnoj praksi koja se prelila i u svakodnevno poslovanje? Mnoge suvremene države u potpunosti su napustile takvu praksu u zadnjim desetljećima. ${ }^{85}$ Štoviše, moglo bi se zaključiti kako je uspostavljena poslovna praksa čak i protivna pozitivnim pravnim propisima (ZOO i ZTD), koji su potpuno usklađeni s postojećom međunarodnom poslovnom praksom. Ako takvo što ne može utjecati na poslovnu praksu i običaje u trgovačkim, potrošačkim i građanskim, takvo što bi trebalo utjecati na javne službe i servise koji, iz nejasnih i neopravdanih razloga, nastavljaju s tom nepotrebnom i zastarjelom praksom u poslovima s trećim osobama. Shodno tomu, zakonodavac bi trebao jasno propisati kako upotreba pečata u pravnom prometu ovisi isključivo o volji pravne osobe odnosno kako javne službe i servisi ne mogu nametati takvu praksu. Osim što se time pojednostavljuje sudjelovanje u pravnom prometu, takvo rješenje pridonosi i olakšanju osnivanja društva zbog smanjenih troškova, a i zbog toga što zastupnici društva ne moraju više čekati izradu pečata kako bi učinili odgovarajuće prijave nadležnim javnim službama, koje bi ionako valjalo automatizirati kroz postupak osnivanja trgovačkog društva.

\section{- Poslovni prostor}

Zamjetnu prepreku početku obavljanja poslovne aktivnosti svakako predstavlja zahtjev porezne uprave o prijavi ugovora o zakupu poslovnog prostora između društva (zakupnik) i druge osobe (zakupodavca). Prijavu tog ugovora porezna uprava redovito traži od tek osnovanog društva pri prijavi u odgovarajući registar poreznih obveznika, bez koje društvo ne može početi legalno obavljati gospodarsku djelatnost. To znači kako mala start-up društva bez značajne početne imovine ne mogu početi obavljati djelatnost u prostoru koji im besplatno ustupi osnivač jer je ugovor o zakupu

11. ožujka 2003. godine.

84 Tako, primjerice, obrasci Porezne uprave (npr. POD-RDG, POD-BIL, P-PDV, PDV-P, JOPPD) i Hrvatskog zavoda za zdravstveno osiguranje (npr. Tiskanica T1 i T2) redovito sadrže mjesto pečata (oznaka M.P.) ili traže pečat osobe podnositelja zahtjeva. Hrvatska udruga banaka u svojim obrascima uplatnica koje domaće banke primjenjuju u poslovanju traže pečat korisnika platnih usluga (npr. obrasci HUB 3 i HUB 3A).

85 Tako, primjerice, pečat više nije potreban u zastupanju pravnih osoba u Njemačkoj, Austriji, Danskoj, Australiji, Sloveniji, gotovo svim državama SAD-a i Ujedinjenom Kraljevstvu. Pritom valja naglasiti kako je nakon početnih neformalnih konzultacija Vlada RH u svibnju 2016. godine pokrenula postupak ukidanja upotrebe pečata, pri čemu je osnovana i radna skupina koja bi trebala pratiti provedbu te reformske mjere. Nažalost, zbog pada vlada u lipnju iste godine, dvojbeno je hoće li se i kako ta mjera provesti. Općenito o pokretanju postupka ukidanja pečata vidi službene stranice Vlade Republike Hrvatske (https://vlada.gov.hr/). 
poslovnog prostora naplatni pravni posao ${ }^{86}$ Kako je ugovor o zakupu naplatni pravni posao, postojanje zakupa nameće izdatke i osnivaču kroz obvezu plaćanja državi poreza na dohodak s naslova imovinskih prava, neovisno o tomu kako posluje njegovo društvo. ${ }^{87}$ Pritom valja naglasiti kako se čini da za takvo sklapanje ugovora o zakupu nema zakonske osnove. ${ }^{88}$ Drugim riječima, iz toga se može zaključiti kako porezna uprava zahtijeva prijavu (sklapanje) takvog ugovora kako bi povećala porezne prihode države. U svakom slučaju, sklapanje toga posla ne smije biti uvjet prijave društva u odgovarajući registar poreznih obveznika. Čak i ako nije uvjet za prijavu, potrebu sklapanja tog posla valja ukinuti jer nepotrebno imovinski i administrativno opterećuje društvo i njegove osnivače. Ako je to volja osnivača treba mu omogućiti osnivanje društava sa sjedištem i poslovnom adresom u stambenom prostoru osnivača bez zakupa tog prostora. Takvo rješenje može pridonijeti poboljšanju poduzetničke klime i rastu malih start-up društva s dobrom poduzetničkom idejom. Eventualnu zlouporabu, kao što je neprijavljivanje zakupa poslovnog prostora, koji ne predstavlja stambeni prostor osnivača, nadležnoj poreznoj upravi i posljedično neplaćanje poreza na dohodak, uvijek je moguće spriječiti postojećim zaštitnim mjerama (npr. naknadnim poreznim nadzorom).

\section{- Dostupnost informacija}

Konačno, valja značajno poraditi i na većoj i kvalitetnijoj transparentnosti informacija o osnivanju društva. Nažalost osnivanje društva u Hrvatskoj uređeno je ,šumom“ zakonskih i podzakonskih propisa. ${ }^{89} \mathrm{Iz}$ takve količine propisa osnivač pravni laik teško će doći do svih potrebnih informacija o postupku i troškovima osnivanja društva. Takve informacije jasno, precizno, točno i potpuno moraju pružiti brojni javni servisi, kao što je ured HITRO.HR, ministarstvo nadležno za poslove gospodarstva i pravosuđa, Hrvatska javnobilježnička komora, gospodarske komore i druga slična udruženja..$^{90}$ Nažalost, autori se ne mogu oteti dojmu kako takva tijela

86 Tako, primjerice, vidi odredbu čl. 5. Zakona o zakupu i kupoprodaji poslovnog prostora kojim se ugovor o zakupu poslovnog prostora određuje kao naplatan pravni posao, a iznos zakupnine kao njegov bitni sastojak.

87 Pritom valja posebno upozoriti na odredbu čl. 28. Zakona o porezu na dohodak, prema kojoj porezna uprava može sama utvrditi dohodak od zakupnine kada takav dohodak nije prijavljen ili nije prijavljen u tržišnom iznosu. To znači kako društvo i osnivač ne mogu sklopiti takav posao sa zakupninom ni u nekom malom simboličkom iznosu radi smanjenja troškova poslovanja, jer će porezna uprava rješenjem tada sama procijeniti iznos poreza prema procijenjenoj tržišnoj vrijednosti zakupa.

88 Zakon o zakupu i kupoprodaji poslovnog prostora nigdje ne nameće dužnost sklapanja tog ugovora pravnim ili fizičkim osoba, već samo određuje koja su temeljna svojstva te prava i obveze iz tog ugovora. Isto vrijedi i za ZOO, kojim je općenito uređen ugovor o zakupu i koji ima dopunjujuću ulogu u odnosu na prvo navedeni propis. Konačno niti Zakon o porezu na dohodak ne određuje takvu dužnost, već samo kriterije utvrđivanja i naplate poreza na dohodak od imovine na temelju zakupa nekretnine.

89 To je, primjerice, ZTD, Zakon o sudskom registru, Zakon o sudskim pristojbama, Pravilnik o načinu upisa u sudski registar, Zakon o javnom bilježništvu, Zakon o javnobilježničkim pristojbama i Pravilnik o privremenoj javnobilježničkoj tarifi.

90 Tako, primjerice, internet stranica ureda HITRO.HR navodi samo općeniti pregled koraka koje je potrebno poduzeti za osnivanje jednostavnog društva s ograničenom odgovornošću bez jasne 
nisu na odgovarajući način pristupila ispunjenju toga zadatka. Zbog toga se prije pokretanja postupka osnivanja redovito ne mogu ni sagledati u potpunosti i precizno sve radnje koje je potrebno poduzeti, kao ni troškovi koji prate takvo osnivanje. Do takvih se informacija redovito dolazi stihijski obilazeći brojne šaltere u izravnom razgovoru s ovlaštenim službenicima i javnim djelatnicima. Stoga valja osigurati javnu dostupnost svih potrebnih i lako razumljivih informacija o osnivanju društva, time više ako se u skladu s prethodno učinjenim prijedlogom omogući online osnivanje društva jer se tada društvo osniva elektronički, bez neposrednoga fizičkog kontakta s nadležnim tijelima (npr. sudskim registrom $\mathrm{i} / \mathrm{ili}$ javnim bilježnikom) ${ }^{91}$ Uzor u tomu mogu poslužiti internet stranice država koje poznaju takvo online osnivanje društava (npr. Ujedinjeno Kraljevstvo i Novi Zeland). ${ }^{92}$

\section{IZMJENE I DOPUNE POSTOJEĆIH ZAKONSKIH RJES̆ENJA}

U ovom poglavlju obrađuju se pojedini dijelovi domaćeg prava društava kod kojih se nametnula potreba izmjene i dopune važećih zakonskih rješenja, kako zbog nužnosti deregulacije i pojednostavljenja postojećeg zakonskog okvira, tako i zbog uklanjanja nastalih nejasnoća. Tako se, primjerice, nameće potreba ujednačavanja pojma koluzije kod zastupanja trgovačkih društava, uređenje pojma poduzeća i pogona, jasnije uređenje pojma zastupanja i vođenja poslova društva te oživljavanja prava glasa dioničara bez toga prava, jasnije uređenje mogućnosti imenovanja članova društva članovima uprave, jasnije uređenje donošenja odluka u nadzornom odboru dioničkog društva i pretpostavki za sazivanje glavne skupštine preporučenim pismom i omogućavanje isplate nagrade članovima prvoga nadzornog odbora dioničkog društva.

- Pojam koluzije u prekoračenju ovlasti kod zastupanja trgovačkih društava

Zastupnici mogu biti ograničeni u zastupanju trgovačkih društva internim ograničenjima. Takva ograničenja određuje zastupani, a djeluju samo između zastupnika i zastupanog. Radi zaštite pravne sigurnosti i povjerenja u pravni promet takva zastupanja djeluju samo između zastupnika i zastupanog. Odredbom članka 48. stavka 1. ZTD-a određeno je kako ograničenja prokure koja nisu predviđena zakonom nemaju učinak prema trećim osobama, „bez obzira“ je li treća osoba za njih znala ili morala znati. S druge strane, u pogledu ostalih oblika zastupanja takva interna ograničenja nemaju učinak prema trećim osobama koje za njih nisu znale niti su morale znati. ${ }^{93}$ Time je koluzija kod prokure uređena bitno blaže nego kod

naznake troškova koji prate takvo osnivanje (http://www.hitro.hr/).

91 Više o online osnivanju i pretpostavkama za takvo osnivanje vidi prethodnu cjelinu „One stop shop usluga i online osnivanje“.

92 Tako, primjerice, za Ujedinjeno Kraljevstvo vidi službenu web stranicu nadležnog registarskog tijela (https://www.gov.uk/government/organisations/companies-house), a za Novi Zeland službenu web stranicu registarskog tijela (https://www.business.govt.nz/companies/).

93 Tako za trgovačku punomoć vidi odredbu čl. 56. st. 3. ZTD-a, a u pogledu ostalih oblika zastupanja tako vidi Barbić, J., Pravo društava, Knjiga prva, Opći dio, 3. izd., str. 475-476, 478479, 481, 491, 502-503, 505-506, 512. 
ostalih oblika zastupanja, jer pravni posao sklopljen suprotno internom ograničenju obvezuje zastupanog unatoč tomu što treća osoba nije u dobroj vjeri odnosno kada je znala ili morala znati za takvo ograničenje. Tako sklopljeni pravni posao ne obvezuje zastupanog samo kada prokurist i treća osoba zlouporabom prava postupaju na štetu zastupanog sklapanjem toga posla odnosno kada treća osoba svjesno postupa na štetu zastupanog. ${ }^{94}$ Iznesenim rješenjem glede prokure, koja je vrsta trgovačke punomoći s najširim opsegom ovlasti, koja se upisuje u sudski registar, odstupa se od učinaka koluzije u poredbenom pravu. ${ }^{95} \mathrm{Za}$ takvo odstupanje u pravilu nema jasnog opravdanja, štoviše, protivno je načelu savjesnosti i poštenja i takvim se rješenjem štiti treća strana koja nije u dobroj vjeri. Izneseno pravilo stoga treba de lege ferenda ujednačiti s drugim pravilima o koluziji (npr. kada uprava djeluje izvan svojih unutarnjih ograničenja u zastupanju društva) kod kojeg zastupani nije vezan poslom ako je treća osoba znala ili morala znati za ograničenje u zastupanju. Drugim riječima, pravni posao sklopljen suprotno unutarnjem ograničenju u zastupanju neće obvezivati zastupanog već kada zbog vlastite grube nepažnje treća strana nije znala za takvo ograničenje. Time se naglasak prebacuje na zaštitu zastupanog.

\section{- Pojam poduzeća i pogona}

Zakonodavac izričito ne određuje pojam poduzeća i pogona, no to ne znači i kako ga domaće pravo društava ne poznaje. Tako se ZTD na više mjesta koristi tim izrazima pri uređenju drugih instituta prava društava. ${ }^{96} \mathrm{Iz}$ toga proizlazi kako domaće pravo pojam poduzeća i pogona shvaća kao sredstvo kojim trgovačko društvo obavlja gospodarsku djelatnost. ${ }^{97}$ Domaća pravna književnost tako određuje poduzeće kao organiziranu gospodarsku (pravnu) cjelinu koju čine objektivni, subjektivni i ustrojbeni sastojci, a putem kojeg nositelj poduzeća djeluje na tržištu. Drugim riječima, radi se o zajednici imovine i osoba te kapitala i rada kojom upravlja nositelj poduzeća radi ostvarenja njegova gospodarskog cilja. ${ }^{98}$ Iako u domaćoj pravnoj književnosti

94 Tako vidi Barbić, J., Pravo društava, Knjiga prva, Opći dio, 3. izd., str. 498-499.

95 U prilog posebnosti takva domaćeg rješenja govori i okolnost da je u njemačkom pravu za koluziju kod prokure načelno dovoljno ako je treća osoba znala ili morala znati za takvo ograničenje u zastupanju. U tom smjeru vidi Weber, K., u: Ebenroth, C, T., Boujong, K., Joost, D., Strohn, L., Handelsgesetzbuch, Band 1, §§ 1-342e, 3. izd., 2014. München, HGB §50 Beschränkung des Umfanges, Rbr. 11-12; Canaris, C., W., Handelsrecht, 24. Auflage, 2006. München, § 12. Die Prokura, Rbr. 35-36.

96 Tako zakonodavac na nekoliko mjesta spominje poduzeće. Primjerice, kod prijenosa tvrtke trgovačkog društva (čl. 23. st. 1. ZTD), kod upisa tvrtke trgovačkog društva u sudski registar (čl. 30. st. 2. ZTD), kod određenja pojma i ovlasti iz trgovačke punomoći (čl. 55. st. 1. ZTD, čl. 56. st. 1. ZTD), kod određenja pojma tajnog društva (čl. 148. st. 1. ZTD), kod osnivanja dioničkog društva unosom poduzeća kao uloga (čl. 181. st. 2. t. 3. ZTD), kod nekih poduzetničkih ugovora (čl. 479. st. 1. ZTD) i kod određenja naravi gospodarskog interesnog udruženja (čl. 584. st. 1. ZTD). S druge strane, pogon se spominje, primjerice, kod određivanja ovlasti skupštine društva s ograničenom odgovornošću (čl. 441. st. 1. ZTD) i kod nekih poduzetničkih ugovora (čl. 480. ZTD).

97 Tako vidi Barbić, J., Pravo društava, Knjiga prva, Opći dio, 3. izd., str. 223.

98 Tako vidi Barbić, J., Pravo društava, Knjiga prva, Opći dio, 3. izd., str. 223, 225. Takvo je određenje poduzeća usporedivo s određenjem njemačke pravne književnosti. Tako vidi Canaris, C., W., Handelsrecht, 24. Auflage, 2006. München, § 12. Die Kaufmannseigenschaft, Rbr. 7. 
nije sporno shvaćanje predmetnog pojma, radi pravne sigurnosti poduzeće bi valjalo jasno urediti u početnom dijelu ZTD-a kojim se određuju i drugi opći pojmovi poput trgovca, trgovačkog društva i trgovca pojedinca. Pritom valja naglasiti kako jedno trgovačko društvo ima samo jedno poduzeće. Pored određenja pojma poduzeća valja odrediti i pojam pogona kao dijela poduzeća koji ima sve tri sastavnice (objektivnu, subjektivnu i ustrojbenu) kao i samo poduzeće. ${ }^{99}$ Pritom valja naglasiti, za razliku od prethodnog određenja u pogledu poduzeća, kako jedno trgovačko društvo može imati više pogona. Određivanje pogona jednako je važno kao i određivanje poduzeća jer pogon, kao i poduzeće, može biti predmetom obveze u pravnom prometa (npr. predmetom poduzetničkog ugovora o zajednici dobiti), a unutarnje ustrojstvo društva i poduzeća može biti organizirano po pogonima koji obavljaju različite gospodarske djelatnosti ili istu djelatnost, ali na različitim mjestima (npr. pogon za proizvodnju mlijeka u Zagrebu i Osijeku ili pogon za proizvodnju mlijeka i pogon za proizvodnju sireva).

\section{- Učinak upisa u sudski registar prema trećim osobama}

Odredbom članka 66. ZTD-a uređen je učinak upisa u sudski registar. ${ }^{100}$ Tako je tom odredbom ponajprije uređeno kako se nitko ne može pozivati na to da mu nisu poznati podatci upisani u sudski registar koji su uredno objavljeni u skladu sa zakonom (st. 1.). Drugim riječima, u vremenu od upisa do objave toga upisa, upis stvara učinak samo prema osobama koje su za njega mogle znati, a nakon objave upisa djeluje i prema svim ostalim. ${ }^{101}$ Odredbom članka 64. stavka 1. ZTD-a određeno je kako upis u sudski registar sud objavljuje bez odgađanja na internetskoj stranici na kojoj se nalazi sudski registar. Štoviše, sljedećim stavkom iste odredbe određeno je kako se smatra da je upis objavljen istekom dana objave na internetskoj stranici sudskoga registra. U praksi se takva objava upisa čini redovito dan nakon donošenja sudske odluke o registarskom predmetu. U tom pogledu sporna je odredba članka 66. stavka 3. ZTD-a prema kojoj se trećim osobama ne mogu suprotstaviti podatci ni isprave iz objave kada se radi o radnjama poduzetim prije šesnaestog dana nakon objave upisa, ako dokažu kako nisu mogle znati za takve objave (st. 3.). ${ }^{102}$ Predmetna odredba rezultat je potrebe usklađivanja s odredbom članka 3. stavka 6. Direktive 2009/101/EZ. ${ }^{103}$ Radi se o iznimci kojom se zapravo prolongira djelovanje učinka upisa u sudski registar prema trećim osobama za najviše šesnaest dana od dana

99 Tako vidi Barbić, J., Pravo društava, Knjiga prva, Opći dio, 3. izd., str. 234-235.

100 Sa stajališta njemačkoga prava vidi usporedivu odredbu $§ 15$. HGB (njem. Handelsgesetzbuch).

101 Tako vidi Barbić, J., Pravo društava, Knjiga prva, Opći dio, 3. izd., str. 548.

$102 \mathrm{U}$ tom smjeru sa stajališta njemačkoga prava vidi usporedivu odredbu §15. st. 2. HGB. Predmetna odredba je ista odredbi čl. 66. st. 3. ZTD-a u svemu, osim u tomu što je njemačkim pravom određen rok od 15 dana od dana objave upisa.

103 Direktiva 2009/101/EZ Europskog parlamenta i Vijeća od 16. rujna 2009. o usklađivanju zaštitnih mjera koje, radi zaštite interesa članova i trećih strana, države članice zahtijevaju za trgovačka društva u smislu članka 48. stavka 2. Ugovora, s ciljem izjednačavanja takvih zaštitnih mjera (kodificirana verzija) (Tekst značajan za EGP) (Sl EU L258/11), koja je zamijenila Direktivu 68/151/EEC od 9. ožujka 1968. godine o koordinaciji zaštitnih mehanizama koje, u svrhu zaštite interesa članica i ostalih, države članice zahtijevaju od društva u smislu čl. 58. st. 2. Ugovora, s ciljem ujednačavanja takvih zaštitnih mehanizama u cijeloj Zajednici. 
objave. Uvjet za takvo odgođeno djelovanje učinka upisa nemogućnost je znanja treće osobe za upisani podatak. Pritom je teško zamisliti okolnosti pod kojima treća osoba neće moći znati za objavu upisa. U tom pogledu domaća pravna književnost daje primjer kako će se o takvoj situaciji raditi kada službeno glasilo Narodne novine nosi raniji datum od datuma kada su stvarno bile dostupne čitateljima, a što se i događalo u praksi. ${ }^{104}$ Međutim, dani primjer više nije primjenjiv jer je naknadno izmijenjena odredba članka 64. ZTD-a prema kojoj se objava upisa ranije vršila u Narodnim novinama, dok se od izmjena i dopuna iz 2009. godine objava vrši na internet stranicama sudskog registra. Kako je objava na internet stranicama registra, po samoj naravi stvari, odmah dostupna javnosti, krajnje je dvojbeno koja se treća osoba uopće može pozivati na to kako mu takva objava nije mogla biti poznata. ${ }^{105}$ Zamislive su eventualno rijetke situacije u kojima takva objava nije dostupna trećim osobama zbog nemogućnosti pristupa internetu, naravno, samo kada krivnja za takvu nemogućnost nije na trećoj osobi. Predmetna odredba, našla bi vjerojatno češću primjenu u situacijama kada se objave upisa u sudski registar vrše u nekom pisanom glasilu. Kako to više nije slučaj u domaćem pravu društava, razumno se nameće pitanje svrhovitosti takvog rješenja. Nažalost, imajući u vidu kako je predmetna odredba rezultat usklađivanja s europskom pravnom stečevinom koja vuče korijene iz 1968. godine, domaći zakonodavac ne može de lege ferenda jednostrano ukloniti takvu odredbu iz zakona. Shodno tomu, valjalo bi utjecati na izmjenu mjerodavnoga europskog pravnog okvira bilo potpunim ukidanjem odgovarajuće norme Direktive 2009/101/EZ ili barem njezinim zadržavanjem u primjeni na države članice kod kojih se objava upisa u sudski registar i dalje vrši objavom u pisanom glasilu. Osnovu za takvo ukidanje valja tražiti u zastarjelosti predmetnog rješenja, a potom i razlozima zaštite pravnog prometa i jačanja povjerenja u ono što je upisano u sudski registar. Tek potom predmetno rješenje treba brisati iz zakona te zadnju rečenicu odredbe članka 66. stavka 3. ZTD-a brisati kao nepotrebnu.

\section{- Prikriveno ulaganje stvari i prava}

Odredbom članka 398. stavka 4. ZTD-a određeno je kako se član društva ne oslobađa obveze uplate uloga ako se njegov ulog u novcu gospodarski ili na temelju onoga što je ugovoreno $u$ vezi $s$ preuzimanjem obveze uplate u potpunosti ili djelomično smatra ulaganjem stvari ili prava. Odredba potom dalje određuje kako ugovori o ulaganju stvari ili prava nisu bez učinka te kako se vrijednost stvari i prava uračunava obvezi uplate uloga u vrijeme podnošenja prijave odnosno prijenosa tih stvari i prava ako prijenos bude izvršen nakon upisa u registar. Zakonodavac pritom izričito određuje kako uračunavanje nije moguće prije upisa društva u sudski registar,

104 Tako vidi Barbić, J., Pravo društava, Knjiga prva, Opći dio, 3. izd., str. 549.

105 Njemačka pravna književnost, primjerice, navodi kako je dužnost svakoga poslovnog partnera i trgovca $\mathrm{i}$ osobe privatnog prava, $\mathrm{u}$ vlastitom interesu provjeriti stanje objave u sudskom registru za subjekta upisa s kojim se namjerava ući u poslovni odnos. Tako vidi Schall, A., u: Heidel, T., Schall, A., Handelsgesetzbuch, Handkommentar, 2. Auflage, 2015., München, HGB $\S 15$ Publizität des Handelsregisters, Rbr. 61-64; Krebs, P., u: Münchener Kommentar zum Handelsgesetzbuch, Band 1, §§ 1-104a, 4. Auflage, 2016., München, GmbHG § 15 Publizität des Handelsregisters, Rbr. 72. 
a teret dokaza vrijednosti stvari i prava leži na članu društva. Iznesena zakonska formulacija, ponajprije, ne daje jasno naslutiti o kakvom se to prikrivenom ulaganju stvari i prava zapravo radi, a potom nije baš jasna ni veza između prvoga dijela odredbe (prikriveno ulaganje stvari i prava) i drugoga dijela odredbe (uračunavanje vrijednosti stvari i prava ulogu). Problem leži ponajviše u tomu što je predmetna odredba unesena u hrvatsko pravo iz njemačkoga prava koje se u velikoj mjeri, u pogledu tumačenje predmetne odredbe, oslanja na svoju sudsku praksu i brojna djela njemačke pravne književnosti. ${ }^{106}$ Iako se iz predmetne odredbe de lege lata može sadržajno dokučiti doseg i značaj predmetnog instituta, radi pravne sigurnosti, tu bi odredbu valjalo de lege ferenda ipak detaljnije urediti.

Do zaobilaženja primjene tih pravila odnosno do ,prikrivenog ulaganja stvari i prava“, primjerice, dolazi tako što član u prvom koraku uplati poslovne udjele u novcu što ne aktivira primjenu zaštitnih pravila. U drugom koraku, društvo i član sklapaju pravni posao (npr. kupoprodaju nekog stroja za proizvodnju u društvu) kojim se član obveže društvu prenijeti određene stvari i prava, a društvo se zauzvrat obveže za te stvari isplatiti određeni iznos novca. Takvom isplatom društvo stječe stvari i prava, a članu se vraćaju novčana sredstva koja je on uplatio za stjecanje poslovnih udjela $u$ društvu. Takvim „prikrivenim unosom stvari i prava“ zaobilaze se uobičajena zaštitna pravila kojima se osigurava da vrijednost unesenih stvari i prava odgovara vrijednosti temeljnoga kapitala koja otpada na uloge koji se uplaćuju unosom stvari i prava u društvo, a zbog čega društvo, a potom i vjerovnici društva mogu trpjeti štetu. ${ }^{107}$ Štetu će trpjeti jer vrijednost stvari i prava koje će biti unesene u društvo imaju manju vrijednost od iznosa temeljnoga kapitala koji otpada na poslovne udjele toga člana. ${ }^{108}$

Vezano uz narav predmetnog pravila, valja naglasiti kako se ono primjenjuje iznimno, samo kada dolazi do prikrivenog ulaganja stvari i prava. ${ }^{109}$ To znači kako

106 Predmetna odredba odgovara odredbi §19. st. 4. GmbHG.

107 To su, primjerice, pravila o navođenju stvari i prava koje se ulažu u društvenom ugovoru odnosno odluci o povećanju temeljnog kapitala, izradi izvješća o osnivanju osnivača, provedbi revizije pri osnivanju, odnosno povećanju temeljnoga kapitala te odgovornosti osnivača i drugih osoba u postupku osnivanja društva. U tom smjeru sa stajališta usporediva njemačkoga prava vidi Ebbing, F., u: Michalski, L., Kommentar zum Gesetz betreffend die Gesellschaften mit beschränkter Haftung (GmbHG), Band 1, §§ 1-34, GmbHG, 2. Auflage, 2010. München, GmbHG, §19 Leistung der Einlagen, Rbr. 130-131; Schwandtner, C., u: Fleischer, H., Goette, W., Münchener Kommentar zum Gesetz betreffend die Gesellschaften mit beschränkter Haftung (GmbHG), Band 1, §§ 1-34, GmbHG, 2. Auflage, 2015., München, §19 Leistung der Einlagen, Rbr. 162.

108 Tako sa stajališta usporediva njemačkoga prava vidi Schwandtner, C., u: Fleischer, H., Goette, W., Münchener Kommentar zum Gesetz betreffend die Gesellschaften mit beschränkter Haftung (GmbHG), Band 1, §§ 1-34, GmbHG, 2. Auflage, 2015., München, §19 Leistung der Einlagen, Rbr. 163.

109 Predmetnim pravilom o prikrivenom ulaganju stvari i prava ostvaruje se zaštita pravila o unosu i održavanju temeljnoga kapitala, kao i nastavak osnivanja kod dioničkog društva. Iako ta pravila imaju istu funkciju, ostvaruju se na bitno različite načine. Više o nastavku osnivanja kod dioničkog društva, vidi Barbić, J., Pravo društava, Knjiga druga, Društva kapitala, Svezak I., Dioničko društvo, 6. izd., str. 338-343. S druge strane, za više o prikrivenom ulaganju stvari i prava vidi Barbić, J., Pravo društava, Knjiga druga, Društva kapitala, Svezak II., Društvo s ograničenom odgovornošću, Društvo za uzajamno osiguranje, Kreditna unija, Europsko 
do upisa društva u sudski registar odnosno povećanja temeljenoga kapitala, u pravilu, ne bi ni smjelo doći prikrivenim ulaganjem stvari i prava jer uprava društva, prema odredbi članka 394. stavka 3. ZTD-a, tada ne bi ni smjela podnijeti registarskom sudu prijavu za upis u sudski registar. ${ }^{10} \mathrm{~S}$ druge strane, registarski sud mora odbiti upis u sudski registar sukladno odredbi članka 395. stavka 2. ZTD-a. ${ }^{111}$ Dođe li do upisa društva u sudski registar ili do povećanja temeljnoga kapitala prikrivenim ulaganjem stvari i prava, valja primijeniti predmetna rješenja. To ponajprije znači kako se član takvim prikrivenim ulaganjem ne oslobađa obveze uplate uloga, a vrijednost stvari i prava koje unese u društvo prikrivenim ulaganjem uračunava se u vrijednosti njegove obveze uplate uloga. Do uračunavanja dolazi ex lege upisom u sudski registar, čak i ako su stvari i prava, koja bivaju predmetom prikrivenog ulaganja, ranije prenesena na društvo, a ako se takav prijenos vrši nakon upisa u sudski registar do uračunavanja dolazi u trenutku prijenosa. ${ }^{112}$ Trenutak uračunavanja mjerodavan je i za utvrđivanje vrijednosti tako unesenih stvari i prava, ali teret dokaza o tomu kako vrijednost unesenih stvari i prava odgovara ili prelazi vrijednost uloga leži na članu društva. Drugim riječima, utvrđuje se objektivna vrijednost stvari i prava utvrđivanjem razlike između vrijednosti imovine društva prije unosa i nakon unosa tih stvari i prava $u$ društvo. ${ }^{113}$ Time se uspostavlja odgovornost člana za razliku između vrijednosti tako unesenih stvari i prava te vrijednosti uloga za preuzete poslovne udjele društva. Bude li vrijednost tako unesenih stvari i prava manja od vrijednosti uloga, za razliku do visine tako izraženog uloga član i dalje odgovara uplatom u novcu. ${ }^{114}$ Shodno tomu, ponajprije valja pojasniti značaj izričaja odredbe o tomu kako ugovori o ulaganju stvari i prava te pravne radnje za njihovo provođenje nisu bez učinka. Iz takvog određenja nije jasno o kakvom se učinku konkretno radi. Shodno tomu, predmetno određenje valja jasnije odrediti na način da se naznači kako takav ugovor ostaje i dalje na snazi,

društvo - Societas Europea (SE), 6. izd., str. 72-74.

110 Povrijedi li uprava tu dužnost, izlaže se kaznenoj odgovornosti sukladno odredbi čl. 624 . ZTD-a, ali i odštetnoj odgovornosti s naslova odredaba čl. 397. i 430. ZTD-a. U tom smjeru sa stajališta njemačkoga prava, vidi Verse, D., A., u: Henssler, M., Strohn, L., Gesellschaftsrecht, 2. Auflage, 2014., München, §19 Leistung der Einlagen, Rbr. 54, 66.

111 U tom smjeru sa stajališta njemačkoga prava vidi Ebbing, F., u: Michalski, L., Kommentar zum Gesetz betreffend die Gesellschaften mit beschränkter Haftung (GmbHG), Band 1, §§ 1-34, GmbHG, 2. Auflage, 2010., München, GmbHG, §19 Leistung der Einlagen, Rbr. 153.

112 U tom smjeru sa stajališta usporediva njemačkoga prava vidi Verse, D., A., u: Henssler, M., Strohn, L., Gesellschaftsrecht, 2. Auflage, 2014., München, §19 Leistung der Einlagen, Rbr. 57; Ebbing, F., u: Michalski, L., Kommentar zum Gesetz betreffend die Gesellschaften mit beschränkter Haftung (GmbHG), Band 1, §§ 1-34, GmbHG, 2. Auflage, 2010., München, GmbHG, §19 Leistung der Einlagen, Rbr. 152.

113 U tom smjeru sa stajališta usporediva njemačkoga prava vidi Schwandtner, C., u: Fleischer, H., Goette, W., Münchener Kommentar zum Gesetz betreffend die Gesellschaften mit beschränkter Haftung (GmbHG), Band 1, § 1-34, GmbHG, 2. Auflage, 2015., München, §19 Leistung der Einlagen, Rbr. 283; Verse, D., A., u: Henssler, M., Strohn, L., Gesellschaftsrecht, 2. Auflage, 2014., München, §19 Leistung der Einlagen, Rbr. 57.

114 To proizlazi iz prve rečenice odredbe članka 398. stavka 4. ZTD-a i odredbe članka 390. stavka 3. ZTD-a. U tom smjeru sa stajališta usporediva njemačkoga prava vidi Verse, D., A., u: Henssler, M., Strohn, L., Gesellschaftsrecht, 2. Auflage, 2014., München, §19 Leistung der Einlagen, Rbr. 58a-59. 
ali se stvari i prava koje društvo stekne s naslova tog ugovora uračunavaju ulogu člana u društvo. Nakon toga, predmetnu odredbu valja dopuniti jasnijim određenjem kako utvrđenu razliku između vrijednosti tako unesenih stvari i prava te vrijednosti uloga mora uplatiti član društva. ${ }^{115}$

\section{- Oživljavanje prava glasa povlaštenim dioničarima bez toga prava}

Prema odredbi članka 296. stavka 2. ZTD-a ako dioničarima bez prava glasa u jednoj godini ne bude isplaćena ili im se samo djelomično isplati povlašteni iznos na ime dobiti pa im se to ni ne nadoknadi u narednoj godini pored punog iznosa koji trebaju primiti za tu godinu, stječu pravo glasa na glavnoj skupštini koje traje sve dok im se ne isplate zaostatci. Iz tako sročene odredbe nije jasno primjenjuje li se izneseno pravilo o oživljavanju prava glasa neovisno o tomu jesu li za pojedinu poslovnu godinu uopće ispunjeni uvjeti za isplatu dobiti dioničarima. Konkretnije, nije jasno je li potrebno da je društvo ostvarilo dobit u poslovnoj godini, je li za oživljavanje prava povlaštenih dioničara možda dovoljno postojanje zadržane dobiti i rezervi koje se mogu koristiti za isplatu dobiti kada poslovanjem nije ostvarena dobit te konačno kako postupiti kada će se u navedenim situacijama donijeti odluka društva o neisplati dobiti. Problem je time veći jer se radi o prisilnoj odredbi od čije primjene nije moguće odstupiti drukčijim određenjem u statutu društva ili u odluci glavne skupštine. Odredba navodi kako se radi o isplati povlaštenog iznosa „na ime dobiti“ iz čega bi se moglo zaključiti kako za oživljavanje prava glasa prethodno moraju biti ispunjeni zakonom određeni uvjeti za isplatu dobiti (dividende) dioničarima (postojanje dobiti i/ili zadržane dobiti pogodne za isplatu dioničarima). ${ }^{116} \mathrm{~S}$ druge strane, suprotno stajalište također ima osnove jer takav zaključak ne proizlazi izravno iz predmetnoga teksta odredbe, a takvom su stajalištu protivna i rješenja poredbenog prava, posebice njemačkoga, koje je bilo uzor domaćem zakonodavcu pri izradi predmetne odredbe. ${ }^{117}$

115 Pritom ne šteti sagledati i druga potencijalna rješenja za prikrivena ulaganja stvari i prava poput, primjerice, solidarne i neograničene odgovornosti svih članova društva za štetu koja nastane društvu zbog takva prikrivenog ulaganja stvari i prava, pri čemu bi takvu odgovornost valjalo ograničiti na manja društva.

116 To su, primjerice, pravila o upotrebi dobiti iz čl. 220. ZTD-a, a posebice st. 7. te odredbe, prema kojem se dioničarima ne smije isplatiti dividenda, ako je u godišnjim financijskim izvješćima za posljednju poslovnu godinu neto aktiva manja od iznosa temeljnoga kapitala uvećanog za iznos rezervi koje se po zakonu ili statutu ne smiju isplatiti dioničarima ili bi postala manja takvom isplatom. Drugim riječima, iznos koji se isplaćuje dioničarima ne smije biti veći od iznosa dobiti iskazane u godišnjim financijskim izvješćima za posljednju poslovnu godinu uvećanog za zadržanu dobit iz ranijih godina i sredstava rezervi koje se mogu koristiti za isplate dioničarima, umanjen za gubitke iz ranijih poslovnih godina te iznose koji su po zakonu ili statutu bili uneseni u rezerve društva.

117 Tako, primjerice, odredbi čl. 296. st. 2. ZTD-a sadržajno odgovara odredba §140. st. 2. AktG-a (njem. Aktiengesetz). Međutim, njemačka odredba ne govori o isplati povlaštenog iznosa na ime dobiti, već samo o isplati povlaštenog iznosa (njem. Vorzugsbetrag). Shodno tomu, prema njemačkom pravu, pravo glasa povlaštenih dioničara oživljava ne bude li im isplaćen u potpunosti ili djelomično takav povlašteni iznos, čak i kada nisu ispunjenje pretpostavke za isplatu dividende ostalim dioničarima. Tako, primjerice, vidi Schröer, H., Doralt, M., u: Goette, W., Habersack, M., Kalss, S., Münchener Kommentar zum Aktiengesetz, Band 3, §§ 118-178, 3. Auflage, 2013., München, §140 Rechte der Vorzugaktionäre, Rbr. 10; Roth, G., u: 
Shodno tomu, iz predmetne odredbe nije jasno u kojim situacijama i u kojem trenutku oživljava pravo glasa povlaštenog dioničara koji inače nema pravo glasa. To bi de lege ferenda izmjenama postojeće odredbe valjalo jasno urediti izborom jedne od dvije prethodno navedene situacije.

\section{- Zastupanje i vođenje poslova društva od strane uprave i prokuriste}

Odredbom članka 242. stavka 2. ZTD-a određeno je kako se članovi uprave dioničkog društva moraju u odnosu na društvo „u vođenju poslova držati ograničenja“ koja su im u okviru propisa postavljena statutom, odlukama nadzornog odbora i glavne skupštine te poslovnikom o radu uprave. S druge strane, odredbom članka 427. stavka 1. ZTD-a određeno je kako članovi uprave društva s ograničenom odgovornošću moraju poštovati „ograničenja ovlasti za zastupanje“ postavljena društvenim ugovorom, odlukom članova društva i obveznim uputama nadzornog odbora. Između dvije navedene odredbe postoji diskrepancija u izričaju jer se u prvoj odredbi govori o ograničenju u vođenju poslova društva, a u drugoj odredbi o ograničenju ovlasti za zastupanje. ${ }^{118}$ Shodno tomu nameće se pitanje radi li se o različitim ili istim ograničenjima zakonskih zastupnika dioničkog društva odnosno društva s ograničenom odgovornošću. Ovlasti vođenja poslova i zastupanja predstavljaju dva različita ovlaštenja uprave društva koja su, doduše, usko povezana i međusobno dopunjujuća. S jedne strane, vođenje poslova društva valja shvatiti kao mjeru internog odnosa koja se odvija u sferi društva, a kada takva mjera izlazi iz te unutarnje sfere radi stvaranja pravnih učinaka u odnosima s trećima govorimo o ovlasti zastupanja. ${ }^{119}$ Iz iznesenoga proizlazi kako svaka mjera vođenja poslova nije nužno i mjera zastupanja (npr. vođenje poslovnih knjiga), no svaka mjera zastupanja predstavlja i mjeru vođenja poslova (npr. odluka uprave o sklapanju određenog pravnog $\mathrm{i}$ sklapanje toga posla $\mathrm{s}$ trećom osobom). ${ }^{120}$ Iako se radi o različitim ovlaštenjima, učinak ograničenja neke od ovlasti u konačnici ne bi trebao dovesti do bitnijih razlika u pravnim posljedicama jer ograničenje u vođenju poslova ujedno predstavlja i ograničenje u zastupanju društva. ${ }^{121}$ Međutim, kako je ograničenje u vođenju poslova društva ipak šire postavljeno jer ono obuhvaća i mjere koje nemaju

Heidel, T., Aktienrecht und Kapitalmarktrecht, 4. Auflage, 2014., Baden-Baden, §140 Rechte der Vorzugaktionäre, Rbr. 6. U tom smjeru ide i domaća pravna književnost pri čemu se jasno ne razlikuje između situacije kada su ispunjeni uvjeti za isplatu redovne dividende i kada takvi uvjeti nisu ispunjeni. Tako vidi Barbić, J., Pravo društava, Knjiga druga, Društva kapitala, Svezak I., Dioničko društvo, 6. izd., str. 583.

118 Predmetna razlika posljedica je preuzimanja zakonskih rješenja njemačkoga prava. Tako u pogledu odredbe čl. 242. st. 2. ZTD-a vidi odredbu §82. st. 2. AktG, a u pogledu odredbe čl. 427. st. 1. ZTD-a vidi odredbu §37. st. 1. GmbHG (njem. Gesetz betreffend die Gesellschaften mit beschränkter Haftung). Kako se u njemačkom pravu radi o dva različita zakonska propisa, predmetna razlika između odredaba nije toliko zamjetna, kao što je to u hrvatskom pravu.

119 U tom smjeru vidi Barbić, J., Pravo društava, Knjiga druga, Društva kapitala, Svezak I., Dioničko društvo, 6. izd., str. 747, 755.

120 Tako sa stajališta usporediva njemačkoga prava vidi Spindler, G., u: Goette, W., Habersack, M., Kalss, S., Münchener Kommentar zum Aktiengesetz, Band 2, §§ 76-117, 4. Auflage, 2014., München, AktG $\S 82$ Beschränkungen der Vertretungs- und Geschäftsführungsbefugnis, Rbr. 6.

121 Tome u prilog vidi Barbić, J., Pravo društava, Knjiga prava, Opći dio, 3. izd., str. 481. 
učinak samo prema trećima, već i prema društvu, valjalo bi kod odredbe članka 427. ZTD-a preuzeti rješenje odredbe članka 242. stavka 2. ZTD-a koje je u tom pogledu opsegom šire jer se radi o ograničenju ovlasti vođenja poslova, a čime ujedno biva ograničena i ovlast zastupanja. ${ }^{122}$ Takvo je rješenje i u skladu s hijerarhijskim odnosom organa društva $s$ ograničenom odgovornošću, a i većom autonomijom članova $u$ uređenju unutarnjih odnosa u društvu nego što je to kod dioničkog društva. Pritom bi, po uzoru na nešto jasnije sročenu odredbu članka 427. stavka 2. ZTD-a, naspram odredbe članka 242. stavka 1. ZTD-a, valjalo naglasiti kako su takva ograničenja bez pravnog učinka prema trećima. Takvim se ujednačavanjem zakonskih rješenja koja načelno proizvode isti učinak pridonosi razumljivosti zakonskog teksta, a i boljem razlikovanju odnosa ovlasti uprave na vođenje poslova i zastupanje društva.

\section{- Računanje suzdržanih glasova pri odlučivanju u glavnoj skupštini i nadzornom odboru dioničkog društva}

Odredbom članka 290. ZTD-a načelo obične većine uspostavlja se kao opće pravilo za donošenje odluka na glavnoj skupštini dioničkog društva. ${ }^{123}$ Drugim riječima, na glavnoj skupštini odluke se donose većinom danih glasova. Pritom zakonodavac nigdje jasno ne određuje kako se točno računa takva većina za donošenje odluka na glavnoj skupštini. Iz odredbe članka 286. stavka 2. točke 3. ZTD-a vidljivo je kako se pri odlučivanju na glavnoj skupštini glas može dati za pojedinu odluku, protiv te odluke, a može se i suzdržati od glasovanja. Prema stajalištu domaće pravne književnosti većina potrebna za donošenje odluke postignuta je kada broj glasova danih za neku odluku bude veći od broja glasova protiv te odluke pri čemu se suzdržani glasovi ne pribrajaju glasovima protiv te odluke. ${ }^{124}$ Istom većinom donose se i odluke u nadzornom odboru odnosno upravnom odboru dioničkog društva. ${ }^{125}$ Tako je za

122 Ograniči li se ovlast vođenja poslova uprave društva u pogledu neke vrste poslova (npr. poslova koji prelaze određenu novčanu vrijednost) to ujedno znači i kako u tim poslovima uprava ne može suprotno postavljenom ograničenju zastupati društvo prema trećima.

$123 \mathrm{Za}$ donošenje pojedinih odluka zakonodavac određuje i posebnu kvalificiranu većinu za donošenje odluke. Tako se, primjerice, za opoziv člana nadzornog odbora zahtijeva donošenje odluke s većinom koja odgovara tri četvrtine danih glasova (čl. 259. st. 1. ZTD), za izmjenu statuta društva traži se većina koja predstavlja tri četvrtine temeljnog kapitala zastupljenog na glavnoj skupštini na kojoj se ta odluka donosi (čl. 301. st. 2. ZTD), a za preoblikovanje dioničkog društva u društvo osoba traži se suglasnost svih dioničara (čl. 571. st. 2. ZTD).

124 Tako vidi Barbić, J., Pravo društava, Knjiga druga, Društva kapitala, Svezak I., Dioničko društvo, 6. izd., str. 1207. Tako sa stajališta usporediva njemačkoga prava vidi Koch, J., u: Hüffer, U., Koch, J., Aktiengesetz, 12. Auflage, 2016., München, §133 Grundsatz der einfachen Stimmenmehrheit, Rbr. 12; Heidel, T., Müller, M., u: Heidel, T., Aktienrecht und Kapitalmarktrecht, 4. Auflage, 2014., Baden-Baden, $\$ 133$ Grundsatz der einfachen Stimmenmehrheit, Rbr. 4.

125 Tako za nadzorni odbor vidi odredbu čl. 267. st. 2. ZTD-a, a za upravni odbor odredbu čl. 272.j st. 3. ZTD-a koja upućuje na odgovarajuću primjenu prethodne odredbe o nadzornom odboru društva. Kod nadzornog i upravnog odbora, međutim, valja paziti na to kada su ti organi podobni za donošenje odluka. Takvi su organi podobni za donošenje odluka ako najmanje polovica propisanoga broja članova sudjeluje u odlučivanju, ali ne manje od tri. Sudjelovanjem u odlučivanju, kao što je prethodno navedeno u tekstu, smatra se davanje glasa za neku odluku, protiv te odluke, ali i suzdržavanje od glasovanja za tu odluku. Više o tome vidi Barbić, J., 
donošenje pojedine odluke $u$ tim organima društva potrebna većina danih glasova pri čemu se ne računaju suzdržani glasovi. ${ }^{126}$ Kako bi se izbjegle potencijalne nejasnoće valjalo bi načelo obične većine jasnije urediti određenjem kako je za donošenje pojedine odluke potrebna većina danih glasova za tu odluku, pri čemu se u glasove za ili protiv ne računaju suzdržani glasovi.

\section{- Imenovanje članova društva kao članova uprave društvenim ugovorom}

Odredba članka 423. stavka 2. ZTD-a prvo određuje kako članovi mogu svojom odlukom imenovati upravu društva ako za takvo imenovanje nije ovlašten netko drugi u društvu. Ista odredba potom određuje kako se za člana uprave može imenovati nekoga od članova društva, a što se može učiniti i društvenim ugovorom za vrijeme dok je član uprave član u društvu. ${ }^{127}$ Iz iznesenoga se može zaključiti kako se članovi uprave mogu imenovati društvenim ugovorom samo ako se radi o članovima društva. Kada to nije slučaj, imenovanje se mora učiniti odlukom članova odnosno odlukom nekoga drugog tijela koje je na to ovlašteno društvenim ugovorom. Izneseno gramatičko tumačenje u suprotnosti je sa stajalištem domaće i usporedive strane pravne književnosti koja smatra kako se društvenim ugovorom mogu imenovati i članovi uprave koji nisu članovi društva. ${ }^{128}$ Takva odredba društvenog ugovora tada se smatra odlukom o imenovanju člana uprave koja nije materijalno(statusno)pravne naravi, već formalnopravne naravi. To znači kako za promjenu člana uprave društva, suprotno stajalištu domaće sudske prakse, nije potrebna odluka skupštine društva za izmjenu društvenog ugovora. ${ }^{129}$ Radi jasnoće, a i radi razjašnjenja naravi takvih odredaba o imenovanju članova uprave društva valja de lege ferenda jasno odrediti kako se osobe koje nisu članovi društva mogu također imenovati društvenim ugovorom pri čemu za promjenu tako imenovanih članova uprave nije potrebna njegova izmjena.

Pravo društava, Knjiga druga, Društva kapitala, Svezak I., Dioničko društvo, 6. izd., str. 942.

126 Tako vidi Barbić, J., Pravo društava, Knjiga druga, Društva kapitala, Svezak I., Dioničko društvo, 6. izd., str. 943.

$127 \mathrm{U}$ tom smjeru vidi usporedivu njemačku odredbu §6. st. 3. GmbHG i austrijsku odredbu $\S 15$. st. 1. GmbH-Gesetz.

128 Tako vidi Barbić, J., Pravo društava, Knjiga druga, Društva kapitala, Svezak II., Društvo s ograničenom odgovornošću, Društvo za uzajamno osiguranje, Kreditna unija, Europsko društvo - Societas Europea (SE), 6. izd., str. 337; Ćesić, Z., u: Gorenc, V., Ćesić, Z., Buljan, V., Brkanić, V., Komentar Zakona o trgovačkim društvima, 4. izd., str. 1015. U tom smjeru sa stajališta njemačkoga prava vidi Zöllner, W., Noack, U., u: Baumbach, A., Hueck, A., GmbHG, Gesetz betreffend die Gesellschaften mit beschränkter Haftung, 20. izd., 2013., München, GmbHG $\S 6$ Geschäftsführer, Rbr. 26, GmbHG § 35 Vertretung der Gesellschaft, Rbr. 7; Stephan, K., Tieves, J., u: Fleischer, H., Goette, W., Münchener Kommentar zum Gesetz betreffend die Gesellschaften mit beschränkter Haftung (GmbHG), Band 2, §§ 35-52, 2. Auflage, 2016., München, GmbhG § 35 Vertretung der Gesellschaft, Rbr. 46.

129 Tako sa stajališta hrvatske pravne književnosti vidi prethodnu bilješku 98. Tako sa stajališta njemačke pravne književnosti, vidi Zöllner, W., Noack, U., u: Baumbach, A., Hueck, A., GmbHG, Gesetz betreffend die Gesellschaften mit beschränkter Haftung, 20. izd., 2013., München, GmbHG $\S 6$ Geschäftsführer, Rbr. 26. Za suprotno stajalište domaće sudske prakse prema kojoj su takve odredbe materijalno(statusno)pravne naravi vidi presudu VTS Pž 3027/033 od 9. prosinca 2006. godine (dostupno na: http://www.iusinfo.hr/). 


\section{- Odlučivanje u nadzornom odboru dioničkog društva pismom i pisanim putem}

Odredba članka 267. stavka 3. ZTD-a određuje kako odsutni članovi nadzornog odbora mogu sudjelovati u donošenju odluka tako da svoj glas dadu pisanim putem. Odredba članka 267. stavka 4. ZTD-a određuje kako se glas u nadzornom odboru može dati pismom i korištenjem drugih podobnih tehničkih sredstava. Pored toga, ista odredba određuje kako se glas tako može dati samo ako se tomu ne usprotivi bilo koji član nadzornog odbora. ${ }^{130} \mathrm{Iz}$ iznesenog ostaje, ponajprije, nejasno je li davanje glasa pisanim putem (st. 3.) i pismom (st. 4.) jedno te isto, a potom utječe li protivljenje jednog člana nadzornog odbora na davanje glasa pismom (st. 4.) i na nemogućnost davanja glasa pisanim putem (st. 3.)? Pomalo je iznenađujuće rješenje domaćeg zakonodavca kojim se prvo određuje kako odsutni član nadzornog odbora glas u nadzornom odboru može dati pisanim putem, a potom se opet (nepotrebno) navodi kako se takav glas može dati pismom. Uvidom u usporedive odredbe njemačkoga prava, koje je našem zakonodavcu poslužilo kao uzor pri izradi predmetnih odredaba ZTD-a, uočljivo je kako između tih odredaba i usporedivih odredaba njemačkoga prava postoji jedna važna razlika. Dok odredba §108. st. 3. AktG-a u potpunosti odgovara odredbi članka 267. stavka 3. ZTD-a, s druge strane, odredba §108. st. 4. AktG-a naizgled isto odgovara odredbi članka 267. stavka 4. ZTD-a, ali uz jednu važnu razliku. Ta odredba njemačkoga prava određuje kako se „odluke nadzornog odbora" mogu donijeti u pisanom obliku, telefonom, telegrafom ako se tomu ne usprotivi nijedan član nadzornog odbora. Njemačko pravo, dakle, govori o obliku odluke nadzornog odbora, a ne načinu na koji član nadzornog odbora može sudjelovati u donošenju takve odluke. ${ }^{131} \mathrm{Za}$ pretpostaviti je, imajući u vidu značajnu sadržajnu podudarnost predmetnih odredaba, kako je takva razlika posljedica pogreške u prijevodu predmetne njemačke odredbe. ${ }^{132}$ Stoga bi de lege ferenda valjalo izmijeniti odredbu članka 267. stavka 4. ZTD-a tako da se onda odnosi samo na oblik odluke glavne skupštine. Time bi se uklonile postojeće nejasnoće i jasno razgraničilo polje primjene između dviju odredaba, pri čemu bi stavak 3. uređivao način ostvarenja prava glasa u nadzornom odboru, a stavak 4. oblik odluke nadzornog odbora. To ne znači kako bi pritom valjalo propustiti priliku unaprjeđenja rješenja iz stavka 3. o načinu na koji članovi nadzornog odbora mogu sudjelovati u odlučivanju nadzornog odbora. Postojeće rješenje samo općenito navodi kako se glas može dati pisanim putem, čime biva isključeno davanje glasa na načine koji nisu pisani (npr. u elektroničkom

130 Tako sa stajališta njemačkoga prava vidi odredbe $\$ 108$. st. 3. i st. 4. AktG.

131 Tako sa stajališta njemačke pravne književnosti vidi Habersack, M., u: Goette, W., Habersack, M., Kalss, S., Münchener Kommentar zum Aktiengesetz, Band 2, §§ 76-117, 4. Auflage, 2014., München, AktG § 108 Beschlußfassung des Aufsichtsrats, Rbr. 52-53, 59-60; Breuer, S., Fraune, C., u: Heidel, T., Aktienrecht und Kapitalmarktrecht, 4. Auflage, 2014., Baden-Baden, AktG $§ 108$ Beschlußfassung des Aufsichtsrats, Rbr. 19.

132 U prilog tom stajalištu govori i prva verzija ZTD (NN 111/93) koja je sadržajno odgovarala AktG prije izmjena i dopuna njemačkog zakona 2001. godine, naravno uz predmetnu grešku u prijevodu. Ta greška nije ispravljena ni kada je predmetna odredba dopunjena 2003. godine (NN 118/03) po uzoru na izmjene i dopune predmetne njemačke odredbe iz 2001. godine. Nakon tih izmjena i dopuna, predmetne odredbe hrvatskog i njemačkog prava nisu se više mijenjale. 
obliku) ${ }^{133}$ Iz domaće i njemačke pravne književnosti proizlazi kako je kod davanja glasa pisanim putem važno utvrđivanje identiteta člana nadzornog odbora. ${ }^{134}$ Zbog toga bi predmetnu odredbu valjalo dopuniti jasnijim određenjem zahtjeva o davanja glasa pisanim putem. Kao uzor u tomu može poslužiti odredba članka 292. stavka 4. ZOO-a kojom je određeno kako je zahtjev pisanog oblika ispunjen kada se iz korištenog sredstva sa sigurnošću može utvrditi, ali i potvrditi sadržaj te identitet davatelja izjave. Konkretno određenje glede toga što zadovoljava tom pravnom standardu valja prepustiti sudskoj praksi (npr. primitak glasa člana o određenoj točki dnevnog reda telefaksom, odnosno elektroničkom poštom, čija je autentičnost potvrđena elektroničkim potpisom, telefonskim pozivom ili pisanim dopisom).

\section{- Pojam poimeničnog poznavanja dioničara kao pretpostavka sazivanja glavne skupštine preporučenim pismom}

Odredba članka 277. stavka 6. ZTD-a određuje kako se glavna skupština može sazvati preporučenim pismom ako su dioničari poimenično poznati društvu. Uobičajeno, prema istoj odredbi poziv na glavnu skupštinu mora se objaviti u glasilu društva. ${ }^{135}$ Shodno tomu, nije jasno kada se smatra da su dioničari društva poimenično poznati društvu, a radi sazivanja glavne skupštine? Znači li to da društvo može sazvati glavnu skupštinu već kada su mu poznata imena svih dioničara, što bi u pravilu redovito trebala biti situacija kada je uredno vođen registar dionica i evidencija dioničara u Središnjem klirinškom depozitoriju? Suprotno tomu, pravna književnosti takvo pozivanje dioničara dodatno pojašnjava navodeći kako bi ono bilo moguće samo kada su društvu poznate njihove adrese. ${ }^{136}$ Shodno tomu valjalo bi jasnije urediti predmetnu odredbu ZTD-a po uzoru na austrijsku odredbu §107.

133 Na predmetnu situaciju nije moguće primijeniti odredbu čl. 292. st. 4. ZOO-a o tomu kada je udovoljeno zahtjevu pisanog oblika, kao i odredbama čl. 293. ZOO i čl. 9. Zakona o elektroničkoj trgovini o sklapanju ugovora elektroničkim putem, jer se radi o odredbama koje se odnose na sklapanje ugovora, a ne i način ostvarenja prava glasa u organu društva.

134 U tom smjeru vidi Barbić, J., Pravo društava, Knjiga druga, Društva kapitala, Svezak I., Dioničko društvo, 6. izd., str. 942. Njemačka pravna književnost, štoviše, smatra kako se glas može dati samo u obliku pisane isprave koju je potpisao član nadzornog odbora. Tako vidi Habersack, M., u: Goette, W., Habersack, M., Kalss, S., Münchener Kommentar zum Aktiengesetz, Band 2, §§ 76-117, 4. Auflage, 2014., München, AktG § 108 Beschlußfassung des Aufsichtsrats, Rbr. 52. S druge strane, dio njemačke pravne književnosti, smatra kako po uzoru na odredbu $§ 108$. st. 4. AktG ne treba strogo inzistirati na zahtjevu pisanog oblika isprave. Tako vidi Breuer, S., Fraune, C., u: Heidel, T., Aktienrecht und Kapitalmarktrecht, 4. Auflage, 2014., Baden-Baden, AktG $§ 108$ Beschlußfassung des Aufsichtsrats, Rbr. 16-18.

135 Tako sa stajališta njemačkoga prava vidi usporedivu odredbe §121. st. 4. AktG, a sa stajališta austrijskoga prava odredbu §107. st. 2. AktG.

136 Tako vidi Barbić, J., Pravo društava, Knjiga druga, Društva kapitala, Svezak I., Dioničko društvo, 6. izd., str. 1162. Tako sa stajališta njemačkoga prava vidi Kubis, D., u: Goette, W., Habersack, M., Kalss, S., Münchener Kommentar zum Aktiengesetz, Band 3, §§ 118-178, 3. Auflage, 2013., München, §121 Allgemeines, Rbr. 78; Koch, J., u: Hüffer, U., Koch, J., Aktiengesetz, 12. Auflage, 2016., München, $\$ 121$ Allgemeines, Rbr. 11b. Tako i sa stajališta austrijskog prava vidi izričitu odredbu §107. st. 2. AktG kao i Oelkers, J., u: Goette, W., Habersack, M., Kalss, S., Münchener Kommentar zum Aktiengesetz, Band 3, §§ 118-178, 3. Auflage, 2013., München, §121 Allgemeines, Rbr. 139. 
st. 2. AktG-a. Tom odredbom određeno je kako društvo može poimenično poznate dioničare pozvati na glavnu skupštinu preporučenim pismom odaslanim na adrese koje su mu poznate ako takvo što nije isključeno statutom društva. Pored toga, valjalo bi po uzoru na liberalnija rješenja njemačkog i austrijskog prava također omogućiti da se statutom društva odrede i drugi načini odašiljanja poziva (npr. elektroničkom poštom i telefaksom). ${ }^{137}$ Time bi se odstupilo od pomalo krutih prisilnih rješenja domaćeg prava, prema kojima poziv dioničaru učinjen odašiljanjem preporučenog pismena na staru adresu ne bi bio valjan. ${ }^{138}$

\section{skupštine \\ - Stavljanje protuprijedloga dioničara prije početka i tijekom glavne}

Odredbom članka 282. stavka 1. ZTD-a prvo se određuje kako se prijedlozi dioničara, uz navođenje njihova imena, obrazloženja i stajališta uprave odnosno izvršnih direktora, moraju učiniti dostupnim određenim osobama (npr. ostalim dioničarima na njihov zahtjev i članovima nadzornog odbora odnosno upravnog odbora), ali samo ako dioničar najmanje četrnaest dana prije održavanja glavne skupštine dostavi društvu svoj protuprijedlog na prijedlog odluke poslovodnog ili nadzornog organa društva odnosno izvršnog direktora o nekoj točki dnevnog reda. Zakonodavac potom uređuje pravila o računanju predmetnog roka te pravila o dostupnosti toga protuprijedloga kod društava čije su dionice uvrštene na uređeno tržište. Na kraju predmetne odredbe određuje se kako nekorištenje spomenutim pravom nema za posljedicu gubitak prava na stavljanje protuprijedloga na glavnoj skupštini društva. ${ }^{139}$ Ovakva konstrukcija i izričaj predmetne odredbe stvaraju nepotrebne dvojbe oko toga može li dioničar staviti takav protuprijedlog na samoj glavnoj skupštini. To proizlazi iz toga što se mogućnost stavljanja takvih protuprijedloga otvara tek zadnjom rečenicom predmetne odredbe, dok se prethodni sadržaj odredbe odnosi isključivo na mogućnost stavljanja protuprijedloga prije održavanja glavne skupštine i samu objavu interesnim skupinama. Pored toga, zadnja rečenica odredbe započinje izričajem „Ako se dioničar ne koristi spomenutim pravo...", pri čemu, imajući u vidu kako se tri prethodne rečenice izravno ne tiču prava na stavljanje protuprijedloga dioničara prije održavanja glavne skupštine, nije baš jasno o kojem se to pravu radi. Pravo na stavljanje protuprijedloga

137 Tako sa stajališta njemačkoga prava vidi Müller, M., u: Heidel, T., Aktienrecht und Kapitalmarktrecht, 4. Auflage, 2014., Baden-Baden, §121 Allgemeines, Rbr. 35; Koch, J., u: Hüffer, U., Koch, J., Aktiengesetz, 12. Auflage, 2016., München, §121 Allgemeines, Rbr. 11f; Kubis, D., u: Goette, W., Habersack, M., Kalss, S., Münchener Kommentar zum Aktiengesetz, Band 3, §§ 118-178, 3. Auflage, 2013. München, §121 Allgemeines, Rbr. 82. Tako sa stajališta austrijskog prava vidi izričitu odredbu §107. st. 2. AktG kojom je određeno kako dioničar može društvu dati elektroničku adresu i pristati na primanje obavijesti na taj način. Više o tome vidi Oelkers, J., u: Goette, W., Habersack, M., Kalss, S., Münchener Kommentar zum Aktiengesetz, Band 3, §§ 118-178, 3. Auflage, 2013., München, §121 Allgemeines, Rbr. 139.

138 Tako vidi Barbić, J., Pravo društava, Knjiga druga, Društva kapitala, Svezak I., Dioničko društvo, 6. izd., str. 1162.

139 Prvi dio predmetne odredbe ZTD-a sadržajno odgovara odredbi §126. st. 1. AktG. Zadnja rečenica predmetne odredbe sadržajem je usporediva odredbi §124. st. 4. AktG. Iz iznesenog proizlazi kako je domaći zakonodavac sadržajno spojio dio odredbe §124. st. 4. AktG i odredbu $\S 126$. st. 1. AktG u odredbi čl. 282. st. 1. ZTD. 
prije glavne skupštine kao i tijekom nje (radi ostvarenja publicitetne funkcije) nije međusobno isključivo, ta prava postoje jednog pored drugog. Dioničar je tako ovlašten uvijek staviti svoj protuprijedlog na samoj glavnoj skupštini, a ako želi da se drugi dioničari i interesne strane upoznaju sa sadržajem njegova protuprijedloga prije održavanja skupštine, takav protuprijedlog mora dostaviti društvu barem četrnaest dana prije održavanja skupštine. ${ }^{140}$ Kako bi se jasnije uredilo predmetno pravo dioničara na stavljanje protuprijedloga prije i tijekom održavanja glavne skupštine valja odmah na početku predmetne odredbe jasno odrediti kako svaki dioničar može staviti svoje protuprijedloge na glavnoj skupštini. Nakon toga bi tek valjalo urediti kako svaki dioničar može dostaviti svoj protuprijedlog društvu četrnaest dana prije održavanja glavne skupštine ako želi da se takav protuprijedlog učini dostupnim zakonom određenim interesnim skupinama (ostalim dioničarima, organima društva). Time bi se jasno razgraničilo pravo dioničara na stavljanje protuprijedloga i pravo na prethodnu objavu danih protuprijedloga.

\section{- Ujednačavanje zakonskog izričaja o zastupanju dioničkog društva i društva s ograničenom odgovornošću uprave}

Odredbom članka 241. stavka 2. i 3. ZTD-a te članka 426. stavka 2. i 3. ZTD-a uređeno je zastupanje dioničkog društva i društva s ograničenom odgovornošću uprave tih društava. ${ }^{141}$ Iako se izričaji tih odredaba razlikuju, funkcionalno imaju isti učinak. ${ }^{142}$ Međutim, upravo takva različitost zakonskih izričaja može dovesti do različitog tumačenja tih odredaba. Tako se, primjerice, za društvo s ograničenom odgovornošću (čl. 426. st. 3. ZTD) navodi kako nije dopuštena odredba u društvenom ugovoru kojom se određuje kako pojedini ili svi članovi uprave zastupaju društvo samo s jednim ili više prokurista. S druge strane, kod dioničkog društva nema takve

140 Tako vidi presudu VTS Pž 1597/03 od 8. srpnja 2003. godine (dostupno na: http://www.iusinfo. hr/). Više o tome vidi Barbić, J., Pravo društava, Knjiga druga, Društva kapitala, Svezak I., Dioničko društvo, 6. izd., str. 1176-1179. U tom smjeru sa stajališta usporediva njemačkoga prava vidi Kubis, D., u: Goette, W., Habersack, M., Kalss, S., Münchener Kommentar zum Aktiengesetz, Band 3, §§ 118-178, 3. Auflage, 2013., München, §124 Bekanntmachung von Ergänzungsverlangen; Vorschläge zur Beschlussfassung, Rbr. 46, 58; Müller, M., u: Heidel, T., Aktienrecht und Kapitalmarktrecht, 4. Auflage, 2014., Baden-Baden, §124 Bekanntmachung von Ergänzungsverlangen; Vorschläge zur Beschlussfassung, Rbr. 26-27.

141 Tako odredba čl. 241. st. 2. ZTD-a određuje kako su kod uprave koja se sastoji od više osoba, a ako statutom nije drukčije određeno, članovi ovlašteni zastupati društvo samo skupno. Pritom je za očitovanje volje prema društvu dovoljno ako je ona očitovana prema jednome članu uprave. Stavkom 3. iste odredbe potom je određeno kako se statutom može odrediti da su za zastupanje ovlašteni pojedini članovi uprave sami ili zajedno s prokuristom. Ako je, međutim, na to ovlašten statutom, takvu odluku može donijeti i nadzorni odbor. S druge strane odredba čl. 426. st. 2. ZTD-a određuje kako članovi uprave skupno zastupaju društvo ako društvenim ugovorom nije određeno drukčije. Pritom se potpisuju tako da uz navođenje tvrtke društva stavljaju svoj potpis. Stavkom 3. iste odredbe određeno je kako se društvenim ugovorom može odrediti da društvo zastupa jedan član uprave samostalno, više njih skupno ili jedan član zajedno s prokuristom ako uprava ima više članova. Pritom nije dopuštena odredba u društvenom ugovoru kojom se određuje kako pojedini ili svi članovi uprave zastupaju društvo samo zajedno s jednim ili više prokurista.

142 Tako vidi Barbić, J., Pravo društava, Knjiga prva, Opći dio, 3. izd., str. 416. 
odredbe zbog čega se valjano nameće pitanje je li rješenje predviđeno odredbom članka 426. stavka 3. ZTD-a za društvo s ograničenom odgovornošću primjenjivo i na dioničko društvo. Narav zakonskoga zastupanja nalaže kako kod dioničkog društva također nije moguće odrediti da pojedini ili više članova uprave mogu zastupati društvo samo s jednim ili više prokurista. Zakonski zastupnici dioničkog društva moraju imati ovlast zastupanja društva bez prokurista. To znači kako određivanje zastupanja zakonskih zastupnika zajedno s prokuristom može imati samo dopunjujuću i pomoćnu funkciju, a ne ograničavajuću funkciju u zastupanju društva. ${ }^{143}$ Pored toga, za dioničko društvo se navodi kako je statutom moguće odrediti kako su na zastupanje ovlašteni „pojedini članovi uprave sami“ (čl. 241. st. 3. ZTD), dok se u tom pogledu za društvo s ograničenom odgovornošću navodi kako se društvenim ugovorom može odrediti da društvo zastupa ,jedan član uprave samostalno“ (čl. 426. st. 3. ZTD). Takva upotreba različitih izražaja, kao i u prethodnom primjeru, nepotrebno stvara pravnu nesigurnost o istom učinku predmetnih zakonskih rješenja. Kako bi se izbjegle takve dvojbe i nejasnoće u pogledu zastupanja dioničkog društva i društva s ograničenom odgovornošću zakonskih zastupnika valja izmijeniti predmetne odredbe kod društva s ograničenom odgovornošću uz navođenje kako se na zastupanje društva uprave društva na odgovarajući način primjenjuju odgovarajuće odredbe o zastupanju dioničkog društva. Tim odredbama valja dodati i odredbu članka 426 . stavka 4. ZTD-a o pasivnom zastupanju društva s ograničenom odgovornošću koja sadržajno odgovara zadnjoj rečenici odredbe članka 241. stavka 2. ZTD-a o pasivnom zastupanju dioničkog društva.

\section{- Sudjelovanje članova uprave na sjednicama nadzornog odbora}

Odredbom članka 266. stavka 1. ZTD-a određeno je kako sjednicama nadzornog odbora „ne mogu“ prisustvovati osobe koje „nisu“ njegovi članovi ili članovi uprave. Iako iz predmetne dvostruke negacije proizlazi kako sjednicama nadzornog odbora mogu sudjelovati osobe koje su njegovi članovi ili članovi uprave, izneseni izričaj valjalo bi radi jasnoće de lege ferenda urediti na način da se izbjegne takva dvostruka negacija. Članovima uprave valja dopustiti da sami odluče hoće li prisustvovati sjednici nadzornog odbora (pri čemu nadzorni odbor može odlučiti da ne budu prisutni kod određenih pitanja), a tek kada nadzorni odbor zatraži njihovu prisutnost na sjednici moraju se s naslova odredbe članka 250. ZTD-a odazvati tom pozivu i prisustvovati na sjednici nadzornog odbora kako bi izvijestili nadzorni odbor o poslovanju društva i djelovanju uprave. ${ }^{144}$ Njihovo sudjelovanje na sjednici nadzornog odbora može pridonijeti učinkovitijem radu nadzornog odbora, jer u slučaju nekih nejasnoća nadzorni odbor može odmah od prisutnih članova uprave

143 Tako vidi Barbić, J., Pravo društava, Knjiga prva, Opći dio, 3. izd., str. 425-426, 428.

144 U tom smjeru vidi Barbić, J., Pravo društava, Knjiga druga, Društva kapitala, Svezak I., Dioničko društvo, 6. izd., str. 813. Tako sa stajališta usporediva njemačkoga prava vidi Habersack, M., u: Goette, W., Habersack, M., Kalss, S., Münchener Kommentar zum Aktiengesetz, Band 2, $\S \S 76-117,4$. Auflage, 2014., München, AktG § 109 Teilnahme an Sitzungen des Aufsichtsrats und seiner Ausschüsse, Rbr. 11-13; Koch, J., u: Hüffer, U., Koch, J., Aktiengesetz, 12. Auflage, 2016., München, $§ 109$ Teilnahme an Sitzungen des Aufsichtsrats und seiner Ausschüsse, Rbr. 3. 
dobiti potrebne informacije koje mu nisu poznate, a kojima raspolaže uprava. Drugim riječima, sudjelovanje članova uprave na sjednicama nadzornog odbora smatra se dobrom praksom korporativnog upravljanja. ${ }^{145}$

\section{- Odobravanje nagrade članovima prvog nadzornog odbora dioničkog društva}

Odredbom članka 269. stavka 2. ZTD-a određeno je kako nagradu članovima prvog nadzornog odbora dioničkog društva može odobriti samo glavna skupština istodobno odlučivanjem o davanju razrješnice. ${ }^{146}$ Iz iznesenog proizlazi kako članovi prvog nadzornog odbora do odobravanja glavne skupštine moraju obavljati svoje dužnosti besplatno. Pored toga, dobivanje takvog odobrenja uvjetovano je davanjem razrješnice članovima tog odbora. Takvo rješenje ne znači samo kako prvi nadzorni odbor do prve glavne skupštine društva mora obavljati svoje dužnosti besplatno, već i kako nagrada koja im se isplaćuje retroaktivno ovisi isključivo o odluci članova društva. ${ }^{147}$ Takvo stanje može izazvati probleme u društvima kod kojih se članovima toga odbora žele imenovati stručnjaci izvan društva. S druge strane, takvo se rješenje pravda zaštitom društva, a posredno i vjerovnika od zlouporaba osnivača. ${ }^{148}$ Kako osnivači imenuju članove prvog nadzornog odbora, u takav se odbor mogu imenovati i osnivači, a određivanje nagrade članovima takvog odbora može poslužiti kao sredstvo zlouporabe kojim bi se isplaćivali izdatci članovima koji se ne mogu opravdati kroz postupak osnivanja. Takvim bi isplatama neposredno društvu, a posredno i vjerovnicima društva nastala šteta. Kako se i jedno i drugo stajalište može pravdati zaštitom opravdanih interesa, interesa imenovanih članova nadzornog odbora te interesom društva i njegovih vjerovnika, valja razmisliti o uvođenju rješenja koje će podjednako uzimati u obzir oba interesa. Tako bi, primjerice, trebalo de lege ferenda omogućiti isplatu nagrade članovima prvog nadzornog odbora i prije donošenja odluke glavne skupštine, dok bi s druge strane, radi zaštite društva i vjerovnika, tako izvršene isplate valjalo odobriti na prvoj glavnoj skupštini društva. Odobrenje bi bilo moguće uskratiti samo djelomično u iznosu koji prelazi primjerenu nagradu za izvršeni rad, pri čemu nepriznati iznos nagrade društvo valja potraživati od članova prvoga nadzornog

145 Tako vidi Breuer, S., Fraune, C., u: Heidel, T., Aktienrecht und Kapitalmarktrecht, 4. Auflage, 2014., Baden-Baden, AktG $§ 109$ Teilnahme an Sitzungen des Aufsichtsrats und seiner Ausschüsse, Rbr. 4.

146 Tako sa stajališta usporediva njemačkoga prava vidi odredbu §113. st. 2. AktG, a sa stajališta usporediva austrijskoga prava odredbu §98. st. 2. AktG.

147 Tako vidi Barbić, J., Pravo društava, Knjiga druga, Društva kapitala, Svezak I., Dioničko društvo, 6. izd., str. 261. Tako sa stajališta usporediva njemačkoga prava vidi Habersack, M., u: Goette, W., Habersack, M., Kalss, S., Münchener Kommentar zum Aktiengesetz, Band 2, §§ 76-117, 4. Auflage, 2014., München, AktG § 113 Vergütung der Aufsichtsratsmitglieder, Rbr. 54; Breuer, S., Fraune, C., u: Heidel, T., Aktienrecht und Kapitalmarktrecht, 4. Auflage, 2014., Baden-Baden, AktG §113 Vergütung der Aufsichtsratsmitglieder, Rbr. 10.

148 U tom smjeru sa stajališta usporediva njemačkoga prava vidi Habersack, M., u: Goette, W., Habersack, M., Kalss, S., Münchener Kommentar zum Aktiengesetz, Band 2, §§ 76-117, 4. Auflage, 2014., München, AktG § 113 Vergütung der Aufsichtsratsmitglieder, Rbr. 54; Koch, J., u: Hüffer, U., Koch, J., Aktiengesetz, 12. Auflage, 2016., München, §113 Vergütung der Aufsichtsratsmitglieder, Rbr. 8. 
odbora odgovarajućom primjenom pravila o zabranjenim plaćanjima (čl. 224. ZTD). ${ }^{149}$

\section{tijela \\ - Imenovanje uprave društva s ograničenom odgovornošću od javnopravnog}

Odredbom članka 423. stavka 2. ZTD-a određeno je kako članovi društva s ograničenom odgovornošću svojom odlukom imenuju upravu društva ako društvenim ugovorom nije predviđeno da je imenuje netko drugi u društvu. Pored toga, odredbom članka 423. stavka 4. ZTD-a određeno je kako se društvenim ugovorom može predvidjeti imenovanje uprave od nekoga javnopravnog tijela. Iz iznesenoga nije jasno može li javnopravno tijelo imenovati članove uprave ako osoba javnog prava nije član toga društva (npr. Republika Hrvatska, grad Zagreb). Takvo rješenje bilo bi protivno načelima na kojima počiva unutarnje uređenje odnosa u društvu (npr. pravu članova na vođenje društva). ${ }^{150}$ Stoga nedovoljno jasnu odredbu članka 423. stavka 4. ZTD-a svakako valja tumačiti u okviru odredbe članka 423. stavka 2. ZTD-a odnosno kako članovi društva redovito imenuju upravu društva, ali na takvo imenovanje može biti ovlašteno i određeno javnopravno tijelo (npr. predstavničko tijelo grada), ako je ono član toga društva i ako je takvo što predviđeno društvenim ugovorom. Ako takvo što nije uređeno društvenim ugovorom, prema odredbi članka 48. stavka 1. točka 6 . Zakona o lokalnoj i područnoj (regionalnoj) samoupravi načelnik, gradonačelnik ili župan ovlašteni su imenovati predstavnike lokalne odnosno područne (regionalne) samouprave u upravu društva s ograničenom odgovornošću. Osim toga, valja posebno naglasiti kako odredba članka 423. stavka 4. ZTD-a uopće nije potrebna jer je ona već obuhvaćena širim izričajem odredbe članka 423. stavka 2. ZTD-a koja govori o tomu kako pravo imenovanje može imati i „netko drugi u društvu“. Shodno tomu, takvu odredbu valja de lege ferenda ukloniti iz zakona, time više jer njezin izričaj, zbog nedovoljne preciznosti, adresate može navesti na krivi zaključak kako ovlast imenovanja uprave društva ima osoba javnoga prava i kada ona nije član toga društva. Takve situacije valja izbjegavati jer je to protivno pravu članova da vode društvo. Pored toga, time se stječe i pogrešan dojam kako se osobe javnog prava posebno privilegiraju u odnosu na ostale treće osobe. To ne znači kako odnos između treće osobe i društva ne bi mogao biti uređen tako da treća osoba, iako nije član društva, može utjecati na imenovanje članova uprave društva. Uređenje takvog odnosa može se postići na obveznopravnoj ili statutarnoj osnovi. Ako se takvo što uređuje na

149 Pritom bi primjenu predmetnog pravila valjalo odgovarajuće proširiti na članove prvog nadzornog odbora. Predmetno bi pravilo valjalo odgovarajuće dopuniti pravilom o nedopuštenim primanjima u pogledu dijela koji se odnosi na nemogućnost namirenja potraživanja članova društva (čl. 407. st. 3. i st. 4. ZTD). Po uzoru na tu odredbu valja dopustiti namirenje potraživanja ne samo kada je to potrebna radi namirenja vjerovnika, već i radi namirenja društva, pri čemu takvo namirenje valja dopustiti samo prema osnivačima koji su sudjelovali u imenovanju članova prvog nadzornog odbora, a ne i ostalih članova društva.

150 Više o tome vidi Barbić, J., Pravo društava, Knjiga druga, Društva kapitala, Svezak II., Društvo s ograničenom odgovornošću, Društvo za uzajamno osiguranje, Kreditna unija, Europsko društvo - Societas Europea (SE), 6. izd., str. 451. U tom smjeru sa stajališta usporediva njemačkoga prava vidi Liebscher, T., u: Fleischer, H., Goette, W., Münchener Kommentar zum Gesetz betreffend die Gesellschaften mit beschränkter Haftung (GmbHG), Band 2, §§ 35-52, 2. Auflage, 2016., München, GmbHG § 46 Aufgabenkreis der Gesellschafter, Rbr. 180. 
obveznopravnoj osnovi, treća osoba nema izravan utjecaj na imenovanje članova uprave, a ako se takvo što uređuje na statutarnoj osnovi, treća osoba ima položaj organa u društvu koji je društvenim ugovorom ovlašten na imenovanje članova ili člana uprave društva. ${ }^{151} \mathrm{U}$ svakom slučaju, odredbu članka 423. stavka 4. ZTD-a valja, kao nepotrebnu, ukloniti iz zakona.

\section{- Odlučivanje članova upotrebom drugih sredstava komunikacije izvan skupštine društva s ograničenom odgovornošću}

Odredbom članka 440. stavka 1. ZTD-a određeno je kako članovi društva s ograničenom odgovornošću u skupštini donose odluke na koje su ovlašteni zakonom i društvenim ugovorom, osim ako se svi članovi u pojedinom slučaju u pisanom obliku ne dogovore o odluci koju valja donijeti ili izjave kako su suglasni s time da se o nekoj odluci glasuje pisanim putem. Iz iznesenog proizlazi kako se odluke skupštine društva redovito donose na skupštini društva, a iznimno pisanim putem. Imajući u vidu izneseno, nameće se pitanje mogu li članovi ostvarivati svoja upravljačka prava koja se odnose na skupštinu društva upotrebom nekih drugih sredstava komunikacije (npr. sredstvima elektroničke komunikacije), a po uzoru na odredbu članka 274. stavka 1. i 2. ZTD-a o ostvarivanju prava dioničara? Imajući u vidu pravilo o većoj slobodi uređenja unutarnjih odnosa u društvu s ograničenom odgovornošću, nego što je to kod dioničkog društva, takvo što je moguće urediti društvenim ugovorom. ${ }^{152}$ Kako u tom pogledu nedostaje izričito zakonsko određenje, a radi uspostave pravne sigurnosti, takvu mogućnost valja de lege ferenda izričito predvidjeti zakonom.

\section{- Sazivanje skupštine jednostavnog društva s ograničenom odgovornošću zbog prijeteće nesposobnosti za plaćanje \\ Odredba članka 390.a stavka 6. ZTD-a određuje kako je u slučaju prijeteće nesposobnosti za plaćanje jednostavnog društva s ograničenom odgovornošću potrebno odmah sazvati skupštinu društva. Čini se kako je predmetna odredba nastala po uzoru na odredbu članka 442. stavka 2. ZTD-a prema kojoj se skupština mora sazvati bez odgađanja kada društvo izgubi polovicu temeljnoga kapitala. Kako jednostavno društvo s ograničenom odgovornošću ima vrlo nizak minimalni iznos temeljnoga kapitala (deset kuna), zahtjev sazivanja skupštine društva nije se mogao vezati uz gubitak polovice temeljnoga kapitala, već se po uzoru na njemačko pravo}

151 Tako vidi Barbić, J., Pravo društava, Knjiga druga, Društva kapitala, Svezak II., Društvo s ograničenom odgovornošću, Društvo za uzajamno osiguranje, Kreditna unija, Europsko društvo - Societas Europea (SE), 6. izd., str. 451-452.

152 U tom smjeru vidi Barbić, J., Pravo društava, Knjiga druga, Društva kapitala, Svezak II., Društvo s ograničenom odgovornošću, Društvo za uzajamno osiguranje, Kreditna unija, Europsko društvo - Societas Europea (SE), 6. izd., str. 440. U tom smjeru sa stajališta usporediva njemačkoga prava vidi Liebscher, T., u: Fleischer, H., Goette, W., Münchener Kommentar zum Gesetz betreffend die Gesellschaften mit beschränkter Haftung (GmbHG), Band 2, §§ 35-52, 2. Auflage, 2016., München, GmbhG $\S 48$ Gesellschafterversammlung, Rbr. 160, 165, 175; Römermann, V., u: Michalski, L., Kommentar zum Gesetz betreffend die Gesellschaften mit beschränkter Haftung (GmbH-Gesetz), Band II, §§ 35-85 GmbHG, §§ 1-4 EGGmbHG, 2. Auflage, 2010., München, GmbHG § 48 Gesellschafterversammlung, Rbr. 282-285, 289. 
vezao uz stanje „prijeteće nesposobnosti za plaćanje“. ${ }^{153}$ Time se nastoji zaštititi društvo i njegove vjerovnike. Iako to nije vidljivo iz izričaja predmetne odredbe, na tako sazvanoj skupštini očekuje se donošenje prikladnih mjera za savladavanje nastalog stanja, oporavak društva i ponovnu uspostavu normalnog poslovanja društva. ${ }^{154} \mathrm{Uz}$ izneseno zakonsko rješenje mogu se postaviti neka pitanja. Tako je ponajprije upitno je li takvo zakonsko rješenje uopće potrebno (čl. 442. st. 2. ZTD). Pored toga, pojam prijeteće nesposobnosti za plaćanje nije uređen predmetnim zakonom. Tu je za pretpostaviti kako se u tom pogledu valja osloniti na Stečajni zakon kojim je uređen pojam ,prijeteće nesposobnosti za plaćanje“, ali i „nesposobnosti za plaćanje“". ${ }^{155}$ Stoga bi se valjalo osloniti na odredbu članka 4. stavka 2. Stečajnog zakona o prijetećoj nesposobnosti za plaćanje pa bi ZTD-om trebalo uputiti na odredbe Stečajnog zakona. Pored toga, ostaje dvojbeno i je li predmetni trenutak odgovarajući za sazivanje skupštine društva, a s ciljem ,ppravovremenog“ donošenja prikladnih mjera za savladavanje takvoga stanja i nastanka težih posljedica za društvo i njegove vjerovnike. Konačno, iz predmetne odredbe može se samo naslućivati što je članovima društva činiti kada sazovu skupštinu zbog prijeteće nesposobnosti za plaćanje. Shodno tomu, valja de lege ferenda ukloniti predmetnu odredbu kao nepotrebnu ili je barem dopuniti tako da se članovima na tako sazvanoj skupštini nametne dužnost poduzimanja prikladnih mjera i donošenja odluka radi zaštite društva i njegovih vjerovnika.

153 Tako sa stajališta njemačkog prava vidi usporedivu odredbu §5a. st. 4. GmbHG. Predmetna njemačka odredba, međutim, posebno naglašava kako takva odredba isključuje primjenu odredbe §49. st. 3. GmbHG koja odgovara odredbi čl. 442. st. 2. ZTD. Shodno tomu, a po uzoru na njemačko pravo valjalo bi odgovarajuće urediti i odredbu čl. 390.a st. 6. ZTD-a jer dužnost sazivanja skupštine prema odredbi čl. 442. st. 2. ZTD-a ne može udovoljiti zahtjevima zaštite društva i vjerovnika imajući u vidu iznimno nizak iznos minimalnog iznosa temeljnoga kapitala društva kod jednostavnog društva s ograničenom odgovornošću. U tom smjeru sa stajališta njemačkoga prava vidi pojašnjenje u Rieder, M., S., u: Fleischer, H., Goette, W., Münchener Kommentar zum Gesetz betreffend die Gesellschaften mit beschränkter Haftung (GmbHG), Band 1, §§ 1-34, GmbHG, 2. Auflage, 2015., München, §5a Unternehmrgesselschaft, Rbr. 35.

$154 \mathrm{U}$ tom smjeru sa stajališta usporediva njemačkoga prava vidi Miras, A., u: Michalski, L., Kommentar zum Gesetz betreffend die Gesellschaften mit beschränkter Haftung (GmbHG), Band 1, §§ 1-34, GmbHG, 2. Auflage, 2010., München, GmbHG, §5a Unternehmrgesselschaft, Rbr. 102.

155 Tako odredba čl. 4. st. 1. Stečajnog zakona određuje kako prijeteća nesposobnost za plaćanje, kao predstečajni razlog, postoji ako sud stekne uvjerenje da dužnik svoje postojeće obveze neće moći ispuniti po dospijeću. Sljedećim stavkom iste odredbe podrobnije je određeno kako će se smatrati da postoji takva nesposobnosti za plaćanje kada nisu nastale okolnosti zbog kojih se smatra da dužnik postao nesposoban za plaćanje i ako se u (i) Očevidniku redoslijeda osnova za plaćanje ima evidentiranu jednu ili više neizvršenih osnova za plaćanje ili (ii) ako duže od 30 dana kasni s isplatom plaće radniku ili (iii) ako u roku od 30 dana ne uplati doprinose i poreze za plaće radnika. S druge strane, odredba čl. 6. st. 1. Stečajnog zakona određuje kako nesposobnost za plaćanje, kao stečajni razlog, postoji ako dužnik ne može trajnije ispunjavati dospjele novčane obveze. Sljedećim stavkom iste odredbe podrobnije je određeno kako će se smatrati da takvo stanje postoji ako u (i) Očevidniku redoslijeda osnova za plaćanje ima evidentiranu jednu ili više neizvršenih osnova za plaćanje u razdoblju duljem od 60 dana ili (ii) ako nije isplatio tri uzastopne plaće radniku. 


\section{- Potreba ujednačavanja nazivlja temeljnih akata društava kapitala}

Osim toga, nameće se i pitanje ujednačavanja naziva temeljnih akata društava kapitala. Tako, primjerice, kod dioničkog društva u postupku osnivanja nalazimo pravne pojmove statut, izjava o osnivanju i izjava o preuzimanju obveze uplate dionica, a kod društva s ograničenom odgovornošću pojmove društveni ugovor $\mathrm{i}$ izjava osnivača o osnivanju društva. ${ }^{156}$ Radi pojednostavljenja zakonskih tekstova, takve bi pravne akte valjalo obuhvatiti jednim aktom i izražavati ih jedinstvenim izrazom statuta, dok bi se izraz društveni ugovor nastavio primjenjivati na društva osoba. Drugim riječima, sadržaj takvih izjava i ugovora bio bi sadržan u jednoj ispravi - statutu društva.

\section{- Razrješnica članovima organa društva s ograničenom odgovornošću}

Odredbom članka 441. stavka 1. točka 1. ZTD-a određeno je kako skupština društva s ograničenom odgovornošću, između ostalog, odlučuje o davanju razrješnice članovima uprave i nadzornog odbora. Imajući u vidu kako članovi društva s ograničenom odgovornošću imenuju i opozivaju članove uprave i nadzornog odbora, pri čemu za opoziv nije potrebno postojanje važnog razloga, nameće se pitanje potrebitosti i funkcije razrješnice kod predmetnog društva. ${ }^{157}$ Naime, ako člana uprave društva s ograničenom odgovornošću članovi mogu opozvati bez ikakva razloga, zašto bi takvi članovi nepotrebno odlučivali o tomu hoće li ili ne, dati tom članu uprave razrješnicu za prethodnu poslovnu godinu. Tomu u prilog govori i položaj izvršnih direktora kod dioničkog društva s monističkim ustrojstvom. Kod takvog dioničkog društva članovi društva ne odlučuju o davanju razrješnice izvršnim direktorima koji operativno vode poslove društva i zastupaju društvo prema trećima, jer za njihov opoziv također nije potrebno postojanje važnog razloga. ${ }^{158}$ Nastali problem posljedica je nedostatne jasnoće postojećih zakonskih rješenja za čije su donošenje uzor bili pravni sustavi država germanskoga pravnog kruga. Tako, primjerice, njemačko pravo predviđa davanje razrješnice članovima uprave $\mathrm{GmbH}$ (§46. st. 1. t. 5. GmbHG), no za razliku od hrvatskoga prava, dugogodišnjom njemačkom sudskom praksom i pravnom književnošću detaljno su razrađeni pravni učinci davanja, odnosno nedavanja razrješnice članovima uprave $\mathrm{GmbH}$. Tako davanje razrješnice članovima uprave ima određeni prekluzivni učinak u odnosu između društva i člana uprave (njem. Präklusionwirkung) koji je čak i sadržajno većeg značaja nego što je to u slučaju razrješnice članovima uprave dioničkog društva. Tako, primjerice, kada član uprave $\mathrm{GmbH}$ dobije razrješnicu ne može biti opozvan zbog poduzimanja radnji za koje je dobio takvu razrješnicu, a protiv njega se ne može postaviti ni odštetni zahtjev u

156 Tako, primjerice, vidi odredbe čl. 173. i čl. 177. ZTD-a za dioničko društvo, a za društvo s ograničenom odgovornošću odredbu čl. 387. ZTD-a.

157 Tako, primjerice, za ovlast imenovanja članova uprave i nadzornog odbora vidi odredbu čl. 441. st. 1. t. 3. i t. 4. ZTD-a, a za opoziv članova uprave odredbu čl. 424. st. 1. ZTD-a i članova nadzornog odbora odredbu čl. 439. ZTD-a.

158 Tako vidi odredbe čl. 275. i 276. ZTD-a koje u pogledu ovlasti glavne skupštine i općenito davanja razrješnice navode samo kako se razrješnica daje članovima uprave, nadzornog odbora odnosno upravnog odbora. 
korist društva u pogledu poduzetih radnji na koje se odnosi dobivena razrješnica. ${ }^{159}$ Kako u hrvatskom pravu ne postoje jasne zakonske prepreke koje onemogućuju takvo shvaćanje razrješnice, moguća je primjena prikazanih rješenja njemačkoga prava u hrvatskom pravu. ${ }^{160}$ Imajući u vidu kako domaće pravo društava ne poznaje davanje razrješnice izvršnim direktorima dioničkog društva, koji se funkcionalno nalaze u sličnoj poziciji kao i direktori društva s ograničenom odgovornošću, u praksi je potpuno razumno shvaćanje o nepotrebnosti instituta razrješnice kod društva $s$ ograničenom odgovornošću. Kako bi se izbjegle daljnje dvojbe u postojanju učinaka i potrebitosti razrješnice kod društva s ograničenom odgovornošću potrebno je jasno opredijeljenje za jedno ili drugo rješenje. Drugim riječima, potrebno je brisati pojam razrješnice iz odredba koje se odnose na društvo s ograničenom odgovornošću ili je potrebno jasnije uređenje pravnih učinaka davanja razrješnice članovima uprave društva s ograničenom odgovornošću po uzoru na rješenja njemačkoga prava. Do tada sudbina pravilne primjene instituta razrješnice kod društva s ograničenom odgovornošću ostaje dvojbena.

\section{ZAKLJUČAK}

Poboljšanje opće gospodarske situacije, rast bruto društvenog proizvoda, smanjenje javnog duga i općenito reforme koje će pridonijeti rastu konkurentnosti domaćeg gospodarstva već su neko vrijeme ciljevi kojima teže domaće vladajuće strukture. Za postizanje tog cilja nije dovoljno djelovanje na samo jednom određenom području, već se traži usklađeno postupanje na više povezanih područja, poput poticanja malog i srednjeg poduzetništva, smanjenja porezne presije, privlačenja inozemnih investicija, liberalizacije tržišta rada i jačanja pravne sigurnosti. Važnu ulogu u tomu ima deregulacija i pojednostavljenje postojećih zakonskih okvira za obavljanje gospodarske djelatnosti. Složeni i ograničavajući propisi, osim što pridonose stvaranju pravne nesigurnosti, također odbijaju strane investicije. U takvom nastojanju promjene negativne gospodarske atmosfere značajnu uloga ima domaće pravo društava kao temeljni okvir za obavljanje gospodarske djelatnosti.

Hrvatsko pravo društvo gradilo se po uzoru na države germanskoga kruga. Unatrag zadnjih desetak godina svjedoci smo promjene načina razmišljanja i u takvim državama koje su počele svoj tradicionalno precizno razrađen i složen sustav

159 Više o tome sa stajališta njemačkoga prava vidi Liebscher, T., u: Fleischer, H., Goette, W., Münchener Kommentar zum Gesetz betreffend die Gesellschaften mit beschränkter Haftung (GmbHG), Band 2, §§ 35-52, 2. Auflage, 2016., München, GmbHG § 46 Aufgabenkreis der Gesellschafter, Rbr. 136, 144, 149-152; Römermann, V., u: Michalski, L., Kommentar zum Gesetz betreffend die Gesellschaften mit beschränkter Haftung (GmbH-Gesetz), Band II, §§ 35-85 GmbHG, §§ 1-4 EGGmbHG, 2. Auflage, 2010., München, GmbHG § 46 Aufgabenkreis der Gesellschafter, Rbr. 277, 286-290.

160 Tako, primjerice, kod društva s ograničenom odgovornošću izostaje odredba čl. 276. st. 2. ZTD-a koja izričito dopušta postavljanje odštetnog zahtjeva prema članovima uprave koji su dobili razrješnicu. Stoga bi se tumačenjem predmetnih odredaba, a contrario, moglo zaključiti kako u slučaju dobivanja razrješnice nije moguće postaviti odštetni zahtjev prema članovima uprave društva s ograničenom odgovornošću. Teško je, međutim, očekivati od adresata norme kako će sami doći do takvog zaključka. 
na nekim područjima deregulirati potaknute natjecanjem između država članica (npr. na području osnivanja trgovačkih društava). Takve promjene nametnule su liberalno progresivnije države članice kao što je Ujedinjeno Kraljevstvo. Hrvatska je u tomu, razumno, odlučila pratiti rješenja njemačkog prava, međutim, takva rješenja redovito nisu u potpunosti prenesena ili tako prenesena nisu dovoljno konkurentna u odnosu na rješenja drugih država članica. Tako, primjerice, unatoč tomu što je iznos temeljnoga kapitala za jednostavno društvo s ograničenom odgovornošću bitno smanjen, kod samog postupka osnivanja nije učinjen dodatan napor radi uklanjanja nepotrebnih administrativnih prepreka. Shodno tomu u postupku osnivanja jednostavnog društva s ograničenom odgovornošću sudjeluju, osim osnivača i nadležnoga sudskog registra, javni bilježnici i brojne javne službe. Želi li se Hrvatska, barem u tom pogledu, učiniti konkurentnijom među državama članicama, trebala bi poduzeti dodatne i hrabrije napore u deregulaciji postojećih zakonskih rješenja. Po uzoru na druge države rad daje cijelo mnoštvo prijedloga, uvažavajući ograničenja koje postavlja europska pravna stečevina, na području osnivanja trgovačkih društava. Takvi napori, međutim, nisu samo mogući na tom području, već i na drugim područjima prava društava kao što je deregulacija i pojednostavljenje strukture pravnih oblika trgovačkih društava.

Osim deregulacije i pojednostavljenja postojećih zakonskih okvira, ne treba zapustiti ni ostala područja zakonodavne aktivnosti, posebice aktivnost usmjerenu na jasnije uređenje postojećih zakonskih rješenja. Tako je s vremenom u poslovnoj i sudskoj praksi primijećeno cijelo mnoštvo zakonskih nejasnoća uzrokovanih nedovoljno jasnim izričajima, kontradiktornostima i neujednačenošću u upotrebi pravnih pojmova. Deregulacija i pojašnjenje postojećih nejasnoća hrvatskoga prava društava mogu bitno pridonijeti rastu konkurentnosti toga prava, a time neizravno i konkurentnosti domaćega gospodarstva. Pritom je važno naglasiti kako izmjenama i dopunama prava društava valja pristupiti stručno, planski, sustavno i oprezno kako se ne bi stvorile dodatne nejasnoće ili se nepotrebno narušila postojeća razina pravne sigurnosti i konkurentnosti.

\section{LITERATURA}

1. Barbić, J., Pravo društava, Knjiga druga, Društva kapitala, Svezak II., Društvo s ograničenom odgovornošću, Društvo za uzajamno osiguranje, Kreditna unija, Europsko društvo - Societas Europea (SE), 6. izd., Zagreb, Organizator, 2013.

2. Barbić, Jakša, Pravo društava, Knjiga druga, Društva kapitala, Svezak I., Dioničko društvo, 6. izd., Zagreb, Organizator, 2013.

3. Barbić, Jakša, Pravo društava, Knjiga prva, Opći dio, 3. izd., Zagreb, Organizator, 2008.

4. Baumbach, Adolf, Hueck, Alfred, GmbHG, Gesetz betreffend die Gesellschaften mit beschränkter Haftung, 20. Auflage, München, C.H. Beck, 2013.

5. Canaris, Claus-Wilhelm, Handelsrecht, 24. Auflage, München, C. H. Beck, 2006.

6. Ebenroth, Carsten Thomas, Boujong, Karlheinz, Joost, Detlev, Strohn, Lutz, Handelsgesetzbuch, Band 1, §§ 1-342e, 3. Auflage, München, C. H. Beck, 2014.

7. Fleischer, Holger, Goette, Wulf, Münchener Kommentar zum Gesetz betreffend die Gesellschaften mit beschränkter Haftung (GmbHG), Band 1, §§ 1-34, GmbHG, 2. Auflage, München, C. H. Beck, 2015.

8. Goette, Wulf, Habersack, Mathias, Kalss, Susanne, Münchener Kommentar zum Aktiengesetz, Band 3, §§ 118-178, 3. Auflage, München, C. H. Beck, 2013. 
9. Gorenc, Vilim, Ćesić, Zlatko, Buljan, Vesna, Brkanić, Vlado, Komentar Zakona o trgovačkim društvima, 4. izd., Zagreb, RRiF-plus, 2008.

10. Goto, Gen, The Outline for the Companies Act Reform in Japan and Its Implications, Journal of Japanese Law, Vol. 18, No. 35/2013., str. 13-38.

11. Heidel, Thomas, Aktienrecht und Kapitalmarktrecht, 4. Auflage, Baden-Baden, Nomos, 2014.

12. Heidel, Thomas, Schall, Alexander, Handelsgesetzbuch, Handkommentar, 2. Auflage, Baden-Baden, Nomos, 2015.

13. Henssler, Martin, Strohn, Lutz, Gesellschaftsrecht, 2. Auflage, München, C. H. Beck, 2014.

14. Hüffer, Uwe, Koch, Jens, Aktiengesetz, 12. Auflage, München, C. H. Beck, 2016.

15. Michalski, Lutz, Kommentar zum Gesetz betreffend die Gesellschaften mit beschränkter Haftung (GmbHG), Band 1, §§ 1-34, GmbHG, 2. Auflage, München, C. H. Beck, 2010.

16. Münchener Kommentar zum Handelsgesetzbuch, Band 1, §§ 1-104a, 4. Auflage, München, C. H. Beck, 2016.

17. Petrović, Siniša, Bilić, Antun, Kemec Kokot, Iva, Provjera identiteta jedinog člana prema Prijedlogu Direktive o Societas Unius Personae, Hrvatska pravna revija, god. XV, br. 6/2015., str. 18-27.

18. van Vliet, Lars, The Netherlands - New Developments in Dutch Company Law: The „Flexible“ Close Corporation, Journal of Civil Law Studies, Vol. 7, Issue 1, 2014., str. 271-286.

19. Williams, G., New Zealand, Corporations and Partnerships, Supplement 5, May 2011. 
Summary

\section{POSSIBLE DIRECTIONS FOR AMMENDMENTS OF CROATIAN COMPANY LAW}

This contribution aims to provide directions for some possible future amendments of domestic company law regulation. Intent of such amendments is to facilitate creation of a more competitive and understandable legal framework that will be equally attractive to both domestic and foreign investors. Establishment of such legal framework can contribute to the strengthening of economy and legal certainty as well as creation of a favourable investment environment. Contribution is divided into two distinct parts. First part provides suggestions relating to amendments in the field of company incorporation. For example, consideration is given to establishment of one stop shop service as well as online incorporation, introduction of the limited liability company without the minimal share capital requirement and other similar areas which can contribute to the simplification of company incorporation procedure (e.g. abolition of the founder's statement of tax debt non-existence). Second part provides suggestions for amendments aimed at improvement of existing legal solutions and removal of ambiguities that undermine legal certainty which can result in non-uniform application in business dealings and judicial practice. For example, suggestions are given in regard to the clearance given to the management and supervisory board members of a private company limited by shares, decision making by shareholders through use of means that do not require them to be physically present at the general meeting of a private company limited by shares, fee approval to the members of the first supervisory board of a public company limited by shares, attendance of management board members at the supervisory board meetings and making counter-proposals by company shareholders before and during the general meeting of the company.

Keywords: company law, company incorporation, public company limited by shares, private company limited by shares, bodies of the company, shareholders.

Zusammenfassung

\section{MÖGLICHE ANLEITUNGEN FÜR ÄNDERUNGEN DES KROATISCHEN UNTERNEHMENSRECHTS}

Der Zweck dieses Beitrags ist es, Anregungen für künftige Änderungen der innerstaatlichen Gesellschaftsregelung anzubieten. Das Ziel solcher Änderungen ist es, die Schaffung eines wettbewerbsfähigeren und verständlicheren Rechtsrahmens zu erleichtern, der sowohl für inländische als auch ausländische Investoren gleichermaßen attraktiv sein würde. Die Festlegung eines solchen Rechtsrahmens könnte zur Stärkung der Wirtschaft und der Rechtssicherheit sowie zur Schaffung 
eines günstigen Investitionsklimas beitragen.

Der Beitrag ist in zwei Teile unterteilt. Der erste Teil enthält Vorschläge für Änderungen auf dem Gebiet der Unternehmensgründung. So wird beispielsweise das folgende berücksichtigt: die Gründung einer One-Stop-Shop Dienstleistung sowie die Online-Gründung, die Einführung der Gesellschaft mit beschränkter Haftung ohne der minimalen Kapitalanforderung und ähnlichen Bereichen, die zur Vereinfachung des Unternehmensgründungsverfahrens beitragen könnten (z.B. die Beseitigung der Aussage von Gründern, dass Steuerschuld nicht existiert).

Der zweite Teil enthält Vorschläge für Änderungen, die auf die Verbesserung bestehender Rechtslösungen und die Beseitigung von Unklarheiten abzielen, welche die Rechtssicherheit beeinträchtigen, was zu einer ungleichmäßigen Anwendung im Geschäftsverkehr und in der gerichtlichen Praxis führen kann. Zum Beispiel, es wurden dem Management und den Mitgliedern des Aufsichtsrates einer Kapitalgesellschaft Vorschläge gemacht, Beschlusserfassungen von Gesellschafter mit anderen Mitteln zu ermöglichen, die es nicht verlangen, dass sie persönlich zur Hauptversammlung der Kapitalgesellschaft erscheinen, Honorargenehmigungen für Mitglieder des Aufsichtsrates einer Kapitalgesellschaft, die Anwesenheit der Vorstandsmitglieder bei Aufsichtsratssitzungen und dem Erstellen von Gegenvorschlägen von Gesellschaftern vor und während der Hauptversammlung des Unternehmens.

Schlüsselwörter: Gesellschaftsrecht, Gesellschaftsgründung, Aktiengesellschaft, GmbH, Organe der Gesellschaft, Gesellschafter.

\section{Riassunto}

\section{POSSIBILI DIREZIONI DI CAMBIAMENTO E DI INTEGRAZIONE DEL DIRITTO SOCIETARIO CROATO}

Il lavoro indirizza verso alcune futuri cambiamenti ed integrazioni del diritto societario interno ai quali si aspira nella creazione di un quadro giuridico più concorrenziale e chiaro che sia ugualmente attraente per gli imprenditori nazionali, che per quelli stranieri. Un quadro normativo concorrenziale e chiaro può rafforzare l'economia interna e la certezza del diritto, creando un clima imprenditoriale più vantaggioso. Il lavoro si divide in due parti principali. Nella prima parte si offrono delle proposte per le modifiche e le integrazioni delle soluzioni giuridiche nell'ambito della costituzione delle società commerciali. Così, ad esempio, si esamina la possibilità di prevedere servizi one stop shop e della costituzione online delle società commerciali; di introdurre delle società di capitali senza il versamento dell'importo minimo del capitale di base; come pure altre possibilità volte a semplificare la costituzione delle società commerciali in Croazia (es. eliminazione della dichiarazione dei costituenti di non essere debitori fiscali). Nella seconda parte del lavoro si analizzano e valutano alcune soluzioni volte al miglioramento di quelle esistenti ed all'eliminazione delle 
imprecisioni che, oltre a minare la certezza del diritto, possono condurre a prassi diversificate nella prassi degli affari ed in quella giurisprudenziale. Così, ad esempio, si suggeriscono delle soluzioni circa la disciplina della possibilità di dare il nulla osta ai membri degli organi delle società a responsabilità limitata, della deliberazione dei soci mediante l'utilizzo di altri mezzi di comunicazione al di fuori dell'assemblea della società a responsabilità limitata, del conferimento del premio ai membri del primo collegio sindacale della società per azioni, della partecipazione dei membri dell'amministrazione alle sedute del collegio sindacale e della presentazione di controproposte degli azionisti prima dell'inizio e durante l'assemblea generale della società.

Parole chiave: diritto societario, costituzione di società commerciale, società per azioni, società a responsabilità limitata, organi della società, azionisti, soci della società. 